\title{
The influence of biomass burning and transport on tropospheric composition over the tropical Atlantic Ocean and Equatorial Africa during the West African monsoon in 2006
}

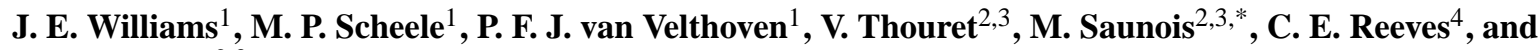 \\ J.-P. Cammas ${ }^{2,3}$ \\ ${ }^{1}$ Royal Netherlands Meteorological Institute, De Bilt, The Netherlands \\ ${ }^{2}$ Université de Toulouse, UPS, LA (Laboratorie d'Aérologie), 14 avenue Edouard Belin, 31400 Toulouse, France \\ ${ }^{3}$ CNRS, LA (Laboratorie d'Aérologie), (UMR 5560), Observatoire Midi-Pyrénées, 31400 Toulouse, France \\ ${ }^{4}$ School of Environmental Sciences, University of East Anglia, Norwich, UK \\ *now at: National Center for Atmospheric Research, Boulder, CO, USA
}

Received: 2 December 2009 - Published in Atmos. Chem. Phys. Discuss.: 23 March 2010

Revised: 24 August 2010 - Accepted: 3 October 2010 - Published: 19 October 2010

\begin{abstract}
Biomass burning (BB) in southern Africa is the largest emission source of $\mathrm{CO}$ and $\mathrm{O}_{3}$ precursors within Africa during the West African Monsoon (WAM) between June and August. The long range transport and chemical processing of such emissions thus has the potential to exert a dominant influence on the composition of the tropical troposphere over Equatorial Africa (EA) and the Tropical Atlantic Ocean (TAO). We have performed simulations using a three-dimensional global chemistry-transport model (CTM) to quantify the effect that continental transport of such BB plumes has on the EA region. BB emissions from southern Africa were found to exert a significant influence over the $\mathrm{TAO}$ and EA between $10^{\circ} \mathrm{S}-20^{\circ} \mathrm{N}$. The maximum concentrations in $\mathrm{CO}$ and $\mathrm{O}_{3}$ occur between $0-5^{\circ} \mathrm{S}$ near the position of the African Easterly Jet - South as placed by the European Centre for Medium range Weather Forecasts (ECMWF) meteorological analysis data. By comparing co-located model output with in-situ measurements we show that the CTM fails to capture the tropospheric profile of $\mathrm{CO}$ in southern Africa near the main source region of the BB emissions, as well as the "extreme" concentrations of both $\mathrm{CO}$ and $\mathrm{O}_{3}$ seen between $600-700 \mathrm{hPa}$ over EA around $6^{\circ} \mathrm{N}$. For more northerly locations the model exhibits high background concentrations in both $\mathrm{CO}$ and $\mathrm{O}_{3}$ related to $\mathrm{BB}$ emissions from southern Africa. By altering both the temporal resolution and the vertical distribution of $\mathrm{BB}$ emissions in the model we show that
\end{abstract}

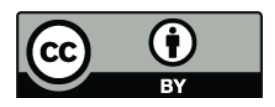

Correspondence to: J. E. Williams (williams@knmi.nl) changes in temporal resolution have the largest influence on the transport of trace gases near the source regions, EA, and in the outflow towards the west of Central Africa. Using a set of trajectory calculations we show that the performance of the CTM is heavily constrained by the ECMWF meteorological fields used to drive the CTM, which transport biomass burning plumes from southern Africa into the lower troposphere of the TAO rather than up towards the middle troposphere at $650 \mathrm{hPa}$. Similar trajectory simulations repeated using an updated meteorological dataset, which assimilates additional measurement data taken around EA, show markedly different origins for pollution events and highlight the current limitations in modelling this tropical region.

\section{Introduction}

The emission of gaseous and particulate matter from both human induced biomass burning (BB) and (natural) wildfires has been identified as the most dominant source of $\mathrm{CO}, \mathrm{NO}_{\mathrm{x}}$ $\left(=\mathrm{NO}+\mathrm{NO}_{2}\right)$, Non-Methane Hydrocarbons (NMHCs), $\mathrm{SO}_{2}$ and aerosol particles in sparsely populated tropical regions (Crutzen and Andreae, 1990; Andreae and Merlet, 2001). The transport and chemical evolution of polluted plumes from BB containing high concentrations of e.g. CO have been shown to affect the composition of the tropopshere at both regional (e.g. Real et al., 2010) and global scales (e.g. de Laat et al, 2006), thus influencing local air quality, visibility and the lifetimes of important greenhouse gases via perturbations in the oxidizing capacity of the troposphere. A

Published by Copernicus Publications on behalf of the European Geosciences Union. 
dominant region where such fires occur is the African continent (e.g. Jain, 2007), where the seasonality of the burning practices results in two distinctive emission phases, one occurring in the Northern Hemisphere (NH), between 0-20 N, and one in the Southern Hemisphere (SH), between 5-20 $\mathrm{S}$. These typically occur between December to March and June to September for the NH and SH, respectively. Moreover, the intensity of fires and the total area burnt in the tropics exhibit a large degree of interannual variability linked to drought conditions imposed during the El Nino-Southern Oscillation. Observations from earth-orbiting satellites are now typically used when assessing the total regional emissions from BB and wildfires for any particular year (e.g. Duncan et al., 2003). Analysing a long term record thus allows such variability to be quantified. For example analysing the total burnt area time series from the Visible and Infrared Scanner (VIRS), the Along Track Scanning Radiometer (ATRS) and Moderate Resolution Imaging Spectroradiometer (MODIS) sensors reveals an inter-annual variability of $\sim 9 \%$ for $\mathrm{NH}$ Africa and $\sim 12 \%$ for SH Africa over the period 1997-2004 (van der Werf et al., 2006). Changes in land use and agricultural practices also introduce a degree of variability, although on longer timescales (e.g. Kull and Laris, 2009). As climate changes, wildfires are likely to increase in both intensity and frequency (e.g. Hoffmann et al., 2009; Flannigan et al., 2009). Hence, the importance of these emission sources for the tropics will potentially be enhanced in the coming decades providing motivation to investigate whether largescale atmospheric models can capture the variability in tropospheric composition which has been observed in the African region in recent years (e.g. Sauvage et al., 2007).

For long-lived trace gases such as $\mathrm{CO}$, convection into the free troposphere results in polluted air-masses traveling long distances (e.g. Staudt et al., 2002; Edwards et al., 2006), where signatures of such events have previously been observed in measurements made in the middle troposphere (MT) over Africa (e.g. Muhle et al., 2002; Hobbs et al., 2003). Indeed Equatorial Africa (EA) exhibits unique meteorological behaviour for June-July-August (JJA) (Nicholson and Grist, 2003), which influences transport in and out of the region. Another important trace species linked to BB is tropospheric ozone $\left(\mathrm{O}_{3}\right)$, which is formed via the photochemical oxidation of $\mathrm{NO}_{2}$ released during burning events. For instance, it has previously been shown that enhanced concentrations of tropospheric $\mathrm{O}_{3}$ in the lower atmosphere over EA between $10^{\circ} \mathrm{N}-10^{\circ} \mathrm{S}$ during July can be attributed directly to emissions from fires near the equator (Sauvage et al., 2005; Sauvage et al., 2007). Moreover, recent aircraft (Reeves et al., 2010; Andrés-Hernàndez et al., 2009) and ozonesonde measurements (Thouret et al., 2009) taken as part of the African Monsoon Multidisciplinary Analysis (AMMA, www.amma-eu.org; Redelsperger et al., 2006) have also shown enhancements in both $\mathrm{CO}$ and $\mathrm{O}_{3}$ at around 4-5 km, especially during August 2006 near the coast of Nigeria, Benin and Ghana. As part of the AMMA project, these enhancements have recently been found to be influenced by BB activity in southern Africa (Real et al., 2010), as well as other emission sources in the Guinea region (Ancellet et al., 2009). However, the transport of such polluted air-masses towards EA is not continuous during the West African Monsoon (WAM), as demonstrated by Mari et al. (2008). They found that during a "break" phase of the African Easterly Jet - South (AEJ-S) between 3-8 August 2006, polluted air-masses were directed back over the continent rather than westwards out over the tropical Atlantic Ocean.

One objective of the AMMA project was to assess the possible shortcomings of current state-of-the-art CTMs for the African continent. A recent intercomparison study has shown that several independent large-scale global CTMs have difficulties in capturing the correct distribution of tropospheric $\mathrm{O}_{3}$ over EA during the WAM as compared with both ozonesonde profiles and a composite of aircraft measurements made during AMMA (Williams et al., 2010). The ability of the CTMs to capture the continental transport and evolution of polluted air-masses is dependent on various model components, such as the chemical mechanism, the convective parameterization, the quality of the meteorological data used to drive the model, the accuracy of the BB emission dataset in terms of the total emission flux introduced per month and the temporal distribution of such emission datasets.

The lofting of BB emissions due to the increased buoyancy of the hot air from the burning process can significantly increase the "effective" injection heights (e.g. Kahn et al., 2007). The fraction of these emissions which are injected directly above the boundary layer (BL) has recently been assessed using satellite observations from both the CloudAerosol Lidar with Orthogonal Polarization (CALIOP) and Multi-angle Imaging SpetroRadiometer (MISR) instruments by Labonne et al. (2007) and Kahn et al. (2008), respectively. These studies concluded that direct emissions are rarely injected above the BL in the tropics (Labonne et al., 2007 ), whereas in boreal regions $\sim 5-18 \%$ reach the free troposphere (Kahn et al., 2008), with injection heights ranging from a few hundred meters to $\sim 4.5 \mathrm{~km}$ above the ground. A statistically robust analysis of MISR observations taken between 2004-2007 over North America (Val Martin et al., 2010) has found that plume height depends on land type, fire intensity, season and local meteorological conditions, with the range in injection heights being similar to that found in Kahn et al. (2008). Therefore, improving the description of BB emissions in globals CTMs requires the application of a vertical profile with which to distribute such emissions throughout the column.

Another factor associated with introducing BB into largescale models is the update frequency of the BB emission inventory. The duration of wildfires and $\mathrm{BB}$ events typically ranges from between a single day to a few weeks, therefore it is desirable that any BB emission inventory is updated 
throughout a month. Such inventories are now available to the atmospheric modelling community e.g. the 8-day Global Fire Emission Database version 2 (GFEDv2) inventory (van der Werf et al., 2006). A number of recent modelling studies performed with CTMs to investigate the effect of regional boreal fire emissions on air quality in North America are somewhat inconclusive concerning the importance of increasing temporal resolution of the emissions and the injection heights for the distribution of such emissions. Some studies have found injection heights to have a larger impact on CTM simulations (e.g. Colarco et al., 2004; Leung et al., 2007; Turquety et al., 2007), whereas others put more emphasis on the temporal resolution in the emission dataset (Chen et al., 2009). Therefore, both of these choices have the potential to be important when simulating atmospheric composition over Africa, where the emission of trace pollutants is typically larger (Jain, 2007).

This study investigates the influence of BB activity in southern and Central Africa during JJA on the composition of the troposphere over EA for the WAM in 2006. Here we differentiate the effect that various modelling parameters (temporal resolution, injection heights, model resolution and emission fluxes) used to describe BB in large-scale CTMs have on capturing both latitudinal and vertical variability for this tropical region. Moreover, by performing a set of trajectory studies around EA, we also differentiate the constraints placed on a global CTM by the quality of the meteorological dataset used to drive the model for the African region. Finally we show the effect of assimilating a more statistically robust set of measurements into the meteorological dataset for August 2006 on the origin of specific air-masses in EA for periods where enhancements of MT $\mathrm{CO}$ and $\mathrm{O}_{3}$ were observed.

This structure of the paper is as follows: in Sect. 2 we describe the model configuration used, the sensitivity studies that have been performed for this investigation, the observational datasets against which model output is compared and give a brief overview of the trajectory model. In Sect. 3 we highlight the differences in the seasonal variability in the mixing ratios of $\mathrm{CO}$ and $\mathrm{O}_{3}$ over the Gulf of Guinea that occur between the various sensitivity studies, and examine the effects of altering model parameters associated with introducing BB emissions into the CTM. In Sect. 4 we compare co-located model output against a variety of different in-situ measurement data relevant for the lower to mid troposphere to assess the performance of the model and examine which model parameters have the largest influence on tropospheric composition. In Sect. 5 we present trajectory analyses to determine the origin of air entering the AMMA measurement region during the WAM, in Sect. 6 we discuss the implications for modelling the tropical regions, and, finally, in Sect. 7, we present our conclusions.

\section{Experimental set up}

\subsection{Model description}

The global CTM used in this study is the Tracer Model version 4 (AMMA version) (TM4_AMMA) model, which adopts a horizontal resolution of $3^{\circ} \times 2^{\circ}$, has 34 levels up to $0.1 \mathrm{hPa}$ and is driven by 6-hourly European Centre for Medium range Weather Forecasts (ECMWF) meteorological analysis data. The main features and parameterizations used in the model are described in Williams et al. (2010), apart from a small number of modifications, of which a brief summary is given here. The heterogeneous uptake co-efficients to account for the scavenging of soluble trace gases into cloud droplets have been updated, where wet deposition is now also included for both methylglyoxal and the lumped aldehyde tracer that is included in the modified CBM4 mechanism to account for higher aldehydes ( $\mathrm{C} 2$ and above, Houweling et al., 1998). The parameterization of Heymsfield and McFarquar (1996) has been included for the description of the microphysical properties of cirrus particles and provides the available cross sectional area of the ice particle field where the resident ice water content is above $10^{-10} \mathrm{~kg} \mathrm{~m}^{-3}$. This cross sectional area is subsequently converted into a surface area density $\left(\mathrm{cm}^{2} / \mathrm{cm}^{3}\right)$ using a scaling ratio of 10 , which has recently been estimated for non-homogeneous randomly shaped particles (Schmitt and Heymsfield, 2005). The effective radius of the ice particles is calculated by using the cross sectional area in the parameterization of $\mathrm{Fu}$ (1996), which has been validated against data from a number of different measurement campaigns both in the tropics and midlatitudes (Heymsfield, 2003). These parameterizations replace the fixed ice particle size of $50 \mu \mathrm{m}$ previously included in TM4_AMMA. The corresponding surface area density available from cloud droplets has also been modified using a fixed cloud droplet radius of $8 \mu \mathrm{m}$. These micro-physical properties are then used for calculating the conversion of $\mathrm{N}_{2} \mathrm{O}_{5}$ into $\mathrm{HNO}_{3}$ on both types of surface according to the approach outlined in Jacob (2000). This modification in the description of the surface area density and an update of the relevant uptake parameters has been shown to reduce the heterogeneous conversion of $\mathrm{N}_{2} \mathrm{O}_{5}$ compared to the fixed values adopted previously, leading to increases in annual means of mid to upper tropospheric $\mathrm{O}_{3}$ of between $\sim 3-5 \%$ and $\mathrm{NO}_{3}$ of between $\sim 25-50 \%$ (Williams et al., 2009b).

For the anthropogenic and biomass burning emissions we retain the inventories from the EU project entitled "Reanalysis of the TROpospheric chemical composition over the past 40 years" (RETRO, http://retro.enes.org/) and GFEDv2 (van der Werf et al., 2006) as used in Williams et al. (2009a). Thus the anthropogenic emissions applied are estimated for the year 2000 and the biomass burning emissions are for 2006, where any increase in anthropogenic emissions in Africa is assumed to have a minimal effect on the results presented here. Due to the $\mathrm{NH}_{3}$ emissions being currently unavailable 
Table 1. Overview of the various sensitivity studies used in the study.

\begin{tabular}{|c|c|c|}
\hline Name of Run & GFEDv2 inventory & Details \\
\hline FULL & Monthly & All biomass burning emissions active \\
\hline NOGUIN & Monthly & $\begin{array}{l}\text { Biomass burning emissions removed between } \\
0-10^{\circ} \mathrm{N}, 20^{\circ} \mathrm{W}-40^{\circ} \mathrm{E}\end{array}$ \\
\hline NOSAFR & Monthly & $\begin{array}{l}\text { Biomass burning emissions removed between } \\
0-40^{\circ} \mathrm{S}, 20^{\circ} \mathrm{W}-40^{\circ} \mathrm{E}\end{array}$ \\
\hline FULL_8day & 8-day & All biomass burning emissions active \\
\hline HIGH_IH & Monthly & $\begin{array}{l}\text { All biomass burning emissions active. Injection height increased } \\
\text { to between } 0-3 \mathrm{~km} \text { above surface, with } 25 \% \text { below } 1 \mathrm{~km}, 50 \% \\
\text { between } 1-2 \mathrm{~km} \text { and } 25 \% \text { placed above } 2 \mathrm{~km} \text {. }\end{array}$ \\
\hline HIGH_CO & 8-day & $\begin{array}{l}\text { As for FULL_8day except the biomass burning emission flux of } \\
\mathrm{CO} \text { between } 0-40^{\circ} \mathrm{S}, 20^{\circ} \mathrm{W}-40^{\circ} \mathrm{E} \text { is increased by } 50 \%\end{array}$ \\
\hline
\end{tabular}

from the GFEDv2 dataset we adopt the 5-year average for the period 1998-2002 from the GFEDv1 dataset as used in recent intercomparison studies (Stevenson et al., 2006). Each emission inventory is supplied on a resolution of $1^{\circ} \times 1^{\circ}$ and subsequently coarsened to $3^{\circ} \times 2^{\circ}$. For this study, we modified the application of the BB emissions in the tropics between $20^{\circ} \mathrm{N}-20^{\circ} \mathrm{S}$ by increasing the maximum injection height to $2 \mathrm{~km}$ as suggested by recent satellite observations of BB plumes (Labonne et al., 2007). This results in $\sim 50 \%$ of the emissions being injected between $0-1 \mathrm{~km}$ and $\sim 50 \%$ being injected between $1-2 \mathrm{~km}$. Moreover, the tropical BB emissions are given a daily cycle to mimic the increased burning in the afternoon, which has been observed from a combination of different satellite instruments that have staggered overpass times (e.g. Boersma et al., 2008) and geostationary platforms (e.g. Giglio, 2007; Roberts et al., 2009). Placing such a constraint on the daily emissions has been found to be important with respect to capturing e.g. the correct distribution of CO in the lower troposphere (LT) (see Chen et al., 2009).

\subsection{Definition of the sensitivity studies}

Here we define a number of sensitivity studies for the purpose of quantifying the importance that regional BB emissions from Africa, and their description in large-scale CTMs, have on the composition of the LT and MT over (near) the Gulf of Guinea during the WAM. An overview of the complete set of simulations performed in the study is given in Table 1.

The baseline simulation (hereafter referred to as FULL) applies BB emissions for all regions using monthly averaged emission inventories from the GFEDv2 database (van der Werf, 2006). Two further simulations are defined where we turn off all BB emissions from Guinea $\left(0-10^{\circ} \mathrm{N}, 20^{\circ} \mathrm{W}-\right.$ $\left.40^{\circ} \mathrm{E}\right)$ and southern Africa $\left(40^{\circ} \mathrm{S}-0^{\circ} \mathrm{N}, 20^{\circ} \mathrm{W}-40^{\circ} \mathrm{E}\right)$ (hereafter referred to as NOGUIN and NOSAFR, respectively), where the seasonality exhibited in the GFEDv2 BB emission inventory for these two regions is similar to that shown in Bian et al. (2007) (i.e. peaks in the BB emissions occur in February and September for the $\mathrm{NH}$ and $\mathrm{SH}$, respectively). For the Sahel $\left(10^{\circ} \mathrm{N}-20^{\circ} \mathrm{N}\right)$ and the Sahara $\left(20^{\circ} \mathrm{N}-40^{\circ} \mathrm{N}\right)$ regions, the annual $\mathrm{BB}$ emission fluxes are low, therefore their influence is assumed to be negligible during the WAM. The trace gases whose emission fluxes are reduced when turning $\mathrm{BB}$ emissions off are $\mathrm{CO}, \mathrm{NO}_{\mathrm{x}}, \mathrm{NMHCs}, \mathrm{SO}_{2}$ and $\mathrm{NH}_{3}$. Figure 1 gives an overview of the African continent, where the regions in which the emissions are turned off in both the NOSAFR and NOGUIN simulations are indicated.

To investigate the sensitivity of in-situ $\mathrm{O}_{3}$ formation and long-range transport of $\mathrm{CO}$ on the injection height of the $\mathrm{BB}$ emissions, we define a simulation where the vertical profile is changed between $30^{\circ} \mathrm{S}-30^{\circ} \mathrm{N}$ compared to the FULL simulation (hereafter referred to as HIGH_IH). Here we base our profile on the vertical distributions derived in Van Martin et al. (2010) from MISR observations for non-boreal land types. This results in no emissions in the first $100 \mathrm{~m}, \sim 25 \%$ of the emissions between $100-1000 \mathrm{~m}, \sim 50 \%$ of the emissions between $1-2 \mathrm{~km}$, and $\sim 25 \%$ between $2-3 \mathrm{~km}$. This is higher than for the other sensitivity studies which use the temperate distribution given in Lavoue et al. (2000). Moreover, these heights are all typically still within the boundary layer over tropical BB regions as suggested by Labonne et al. (2007) for southern Africa, where the application of the daily cycle ensures that the boundary layer is well developed when the majority of the emissions are injected (in the afternoon).

To explore the effect of temporal resolution of the BB emission fluxes, a simulation is performed using the GFEDv2 8-day emission inventory (van der Werf et al., 2006) (hereafter referred to as FULL_8day), where the flux estimates are updated every 8 days resulting in changes to the BB emission fluxes 3-4 times every month. Moreover, the total integrated emission flux for species that are introduced into the model for JJA between the monthly and 8-day GFEDv2 inventories may be slightly different as a result of the coarsening step. 


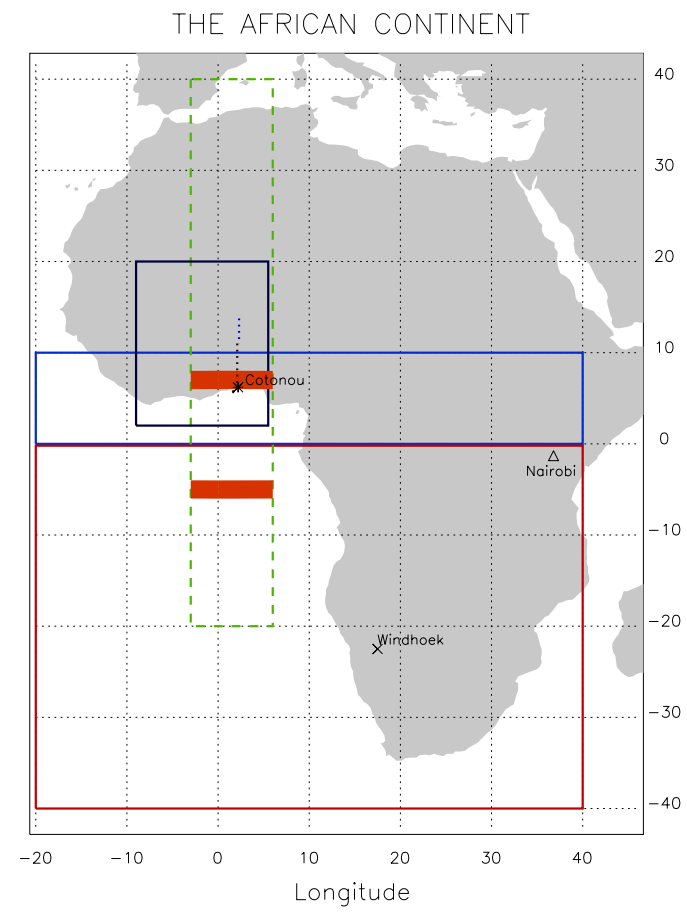

Fig. 1. An overview of the African Continent and the location of both the different biomass burning regions and the measurement sites used in this study. For the NOGUIN simulation the BB emissions are removed within the dark blue box and for the NOSAFR simulation the BB emissions are removed within the red box. The 2-D transect is shown as the green dashed line. The location of the Cotonou (Benin) and Nairobi (Kenya) ozonesonde stations are shown, along with the location of the MOZAIC airport at Windhoek (Namibia). The black box shows the region in which the flights from the AMMA campaign took place during July and August, 2006. The location of the BAe-146 flights on the 13 August (black) and 14 August (blue) of August are shown as the two dotted lines.

Finally, since the estimation of $\mathrm{CO}$ emissions from $\mathrm{BB}$ depends on the methodology (type of instrument, sampling frequency, etc.) and type of data used, significant uncertainties exist between different inventories (e.g. Ito and Penner, 2005; Monks et al., 2009; Stroppiana et al., 2010). We therefore define another sensitivity test where the emission of $\mathrm{CO}$ from BB is increased by $50 \%$ in southern Africa during JJA in order to increase its atmospheric burden during the WAM (hereafter referred to as $\mathrm{HIGH}_{-} \mathrm{CO}$ ). This results in an increase of 21.6 Tg CO over JJA for 2006.

\subsection{Trajectory calculations}

In order to provide further information regarding the origin of air-masses for specific days in EA we perform additional calculations with the TRAJKS trajectory model (Scheele et al., 1996). Here we use the same 6-hourly ECMWF operational datatset as that is used to drive TM4_AMMA, but at a $0.5^{\circ} \times 0.5^{\circ}$ resolution. This trajectory model uses the iterative scheme of Petterssen (1940) and has been shown to compare favorably with other trajectory models used by the atmospheric sciences community (Stohl et al., 2001). Neither diffusion nor convection are accounted for in the model. We use TRAJKS in this study to perform both 10-day backward and forward trajectory calculations on selected air-masses at various altitudes in order to derive their origin, which we are unable to do using a Eulerian CTM such as TM4_AMMA.

\subsection{Observations}

To assess the potential improvements in model performance between the various sensitivity studies we exploit a variety of measurement datasets, of which we give a brief description below.

The Measurement of OZone, water vapour, carbon monoxide and nitrogen oxides by airbus in-service AIrCraft (MOZAIC) measurement programme makes in-situ measurements of both $\mathrm{CO}$ and $\mathrm{O}_{3}$ using instruments housed on passenger aircraft at a precision of $\sim 5 \mathrm{ppbv}$ and $\sim 1 \mathrm{ppbv}$, respectively (Nédélec et al., 2003; Thouret et al., 1998). This provides both vertical profiles during take-off and landing and in-flight data in the Upper Troposphere - Lower Stratosphere (UTLS). During 2006 atmospheric profiles of both trace gas species were taken at Windhoek, Namibia $\left(22.5^{\circ} \mathrm{S}\right.$, $17.5^{\circ} \mathrm{E}$ ), where the location of the airport is shown in Fig. 1. Measurements were made during both day and night thus (partly) capturing the effects of the daily cycle of BB activity and the diurnal variations in photochemical activity.

The Southern Hemisphere ADditional OZonesonde (SHADOZ) network provides a time series of ozonesonde measurements made throughout the tropics (Thompson et al., 2003). We use the measurements from this dataset taken in EA at Cotonou $\left(6.2^{\circ} \mathrm{N}, 2.2^{\circ} \mathrm{E}\right)$ and Nairobi $\left(1.3^{\circ} \mathrm{S}, 36.8^{\circ} \mathrm{E}\right)$ during JJA 2006, where an overview of the Cotonou measurements is given in Thouret et al. (2009). It has been shown that measurements of this type have an accuracy of $\sim 5-10 \%$ (e.g. Deshler et al., 2008). Both stations are situated near large urban conurbations, although Cotonou is near the coast and therefore subject to more varying types of circulation whereas Nairobi is situated much further east (see Fig. 1) and not affected by the same dynamics. The two other stations situated at Malindi $\left(3.0^{\circ} \mathrm{S}, 40.2^{\circ} \mathrm{E}\right)$ and Irene $\left(25.9^{\circ} \mathrm{S}\right.$, $\left.28.2^{\circ} \mathrm{E}\right)$ had limited or missing data for our chosen period and therefore were not used.

A dedicated airborne measurement campaign was performed around EA during the WAM 2006 as part of the AMMA project (Reeves et al., 2010). Here we utilise the measurements of CO taken in the LT and MT by the French Falcon (F-F20), German Falcon (D-F20), ATR-42 and BAe146, where the precision for $\mathrm{CO}$ measured on e.g. the BAe146 is typically $\sim 5 \%$. We also use selected $\mathrm{O}_{3}$ measurements from the BAe-146, where the precision for this species is typically $\sim 3 \%$ (www.faam.ac.uk). An intercomparison 
was made between participating aircraft in the airborne campaign to provide confidence regarding potential biases (Reeves et al., 2010). The data used here has been corrected for such biases according to the scaling factors given in Reeves et al. (2010). Flights were made between $2-21^{\circ} \mathrm{N}$ and $10^{\circ} \mathrm{W}-7^{\circ} \mathrm{E}$. Measurements taken in EA from these aircraft have also been used in previous studies concerned with EA (e.g. Real et al., 2010; Williams et al., 2010).

\section{The simulated influence of biomass burning from dif- ferent regions and approaches used for BB activity on tropical tropospheric composition}

In this study we use the same 2-D cross section defined for the AMMA Model Intercomparison Project (AMMA-MIP, Williams et al., 2010), which contains averages of tracer concentrations between $3^{\circ} \mathrm{W}-6^{\circ} \mathrm{E}$ for a latitude range of $20^{\circ} \mathrm{S}-$ $40^{\circ} \mathrm{N}$. Figure 1 shows the location of the transect with respect to the African continent. This 2-D cross section passes over the Cotonou measurement site $\left(6.2^{\circ} \mathrm{N}, 2.2^{\circ} \mathrm{E}\right)$, where ozonesonde observations were made during 2005 and 2006 (Thouret et al., 2009), and also the location where instrumented aircraft flights were conducted during the AMMA measurement campaign (e.g. Reeves et al., 2010). For analysis of the model performance selected tracer fields are written out every three hours, which are then averaged to produce both monthly and daily values. In order to differentiate between air that originates from southern Africa, local convection or the background we also included two chemically passive tracers. These "region" tracers for Guinea and southern Africa are given a fixed atmospheric lifetime of 20 days, where concentrations are fixed at $100 \mathrm{pptv}$ below $850 \mathrm{hPa}$ (over land) for both of the regions used in the study. For grid cells which contain both land and ocean a scaling is applied, where the fixed concentration is weighted with the land fraction. By showing the daily variability in $\mathrm{CO}$ and $\mathrm{O}_{3}$ with the respective passive tracers we examine the fluctuations in transport into the region using 6-hourly updates of the meteorological fields.

\subsection{Monthly comparisons}

Figures 2 and 3 show the distribution of tropospheric $\mathrm{CO}$ and $\mathrm{O}_{3}$ in the 2-D cross section for the FULL simulation, respectively. Examining the tropospheric distribution for both species reveals that the maximum values typically occur around $0-5^{\circ} \mathrm{S}$ between $700-850 \mathrm{hPa}$. This maximum has been shown to occur at similar locations for a range of different CTMs (Williams et al., 2010) using the AMMABB emission inventory (Liousse et al., 2010). The location of this maximum corresponds to the mean position of the AEJ-S as shown in Mari et al. (2008). Looking at the associated differences between the NOGUIN and NOSAFR simulations shows that the influence of $\mathrm{BB}$ in southern
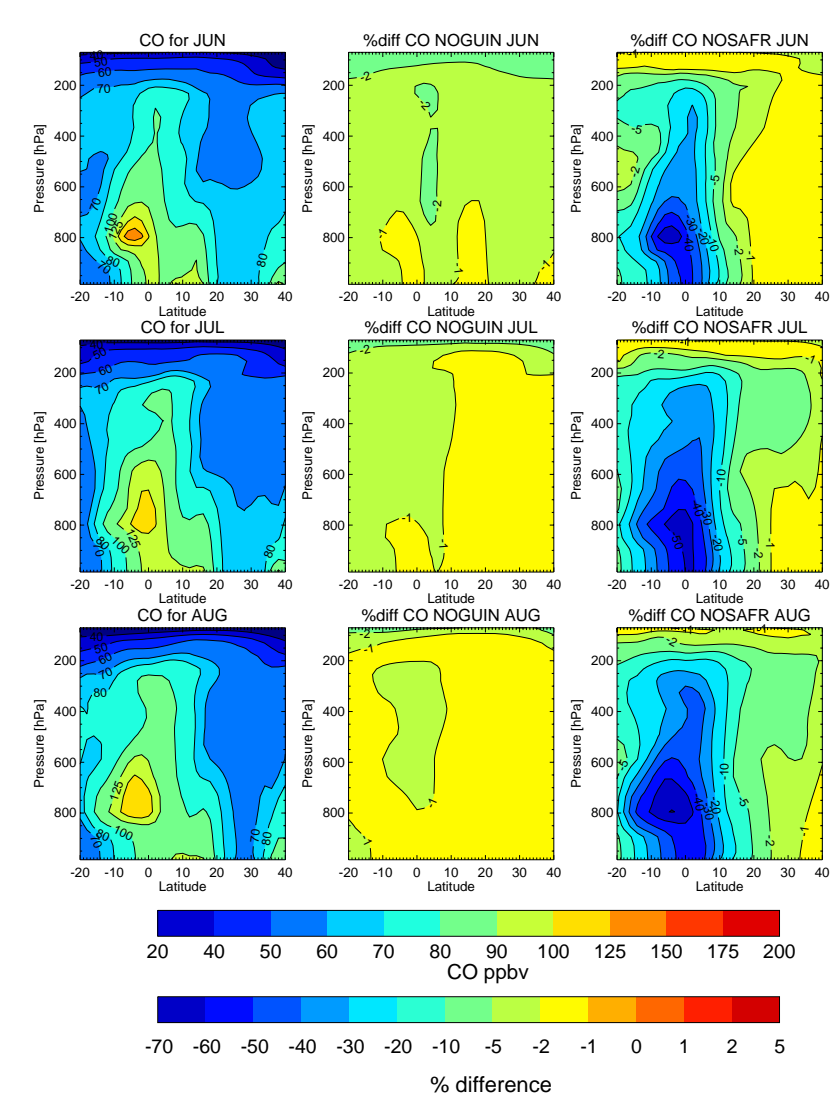

Fig. 2. The influence of regional $B B$ emissions on monthly mean mixing ratio of $\mathrm{CO}$ given in ppbv along the 2-D cross section taken between $3^{\circ} \mathrm{W}-6^{\circ} \mathrm{E}$ during June, July and August in 2006. The distribution of tropospheric CO is shown for the FULL simulation (left column) along with the differences for the NOGUIN (middle) and NOSAFR (right) simulations. The differences are calculated as $($ SENS-FULL)/FULL $\times 100$.

Africa dominates the composition of the 2-D transect, where there are $\sim 40-50 \%$ reductions in both trace species below $500 \mathrm{hPa}$ between $5^{\circ} \mathrm{S}-5^{\circ} \mathrm{N}$ for NOSAFR. Moreover, the differences in the NOSAFR simulation extend far inland over West Africa reaching $\sim 10-20^{\circ} \mathrm{N}$. Analysing the emission totals during JJA for the tropics and subtropics shows that the NOGUIN (NOSAFR) simulation exhibits reductions of $\sim 0.1 \mathrm{Tg}(\sim 44.9 \mathrm{Tg})$ in $\mathrm{CO}, \sim 0.01 \mathrm{Tg}(\sim 0.76 \mathrm{Tg})$ in $\mathrm{NO}_{\mathrm{x}}$, $\sim 0.03 \mathrm{Tg}(\sim 1.3 \mathrm{Tg})$ in $\mathrm{C}$ (from VOC's excluding isoprene) and very small differences in both $\mathrm{SO}_{2}$ and $\mathrm{NH}_{3}$. This causes reductions in the tropical tropospheric burdens of $\mathrm{CO}$ and $\mathrm{O}_{3}$ below $500 \mathrm{hPa}$ of $\sim 2.0 \%(\sim 17.1 \%)$ and $\sim 0.6 \%(\sim 7.5 \%)$, respectively, when integrated between $34^{\circ} \mathrm{N}-34^{\circ} \mathrm{S}$ over longitudes $20^{\circ} \mathrm{W}-40^{\circ} \mathrm{E}$. Thus, BB emissions from southern Africa have a strong influence on the oxidative capacity of the troposphere over EA (where the resident $\mathrm{OH}$ is typically governed by the resident $\mathrm{O}_{3}$ ), especially for the $\mathrm{LT}$ (see Sect. 4). 


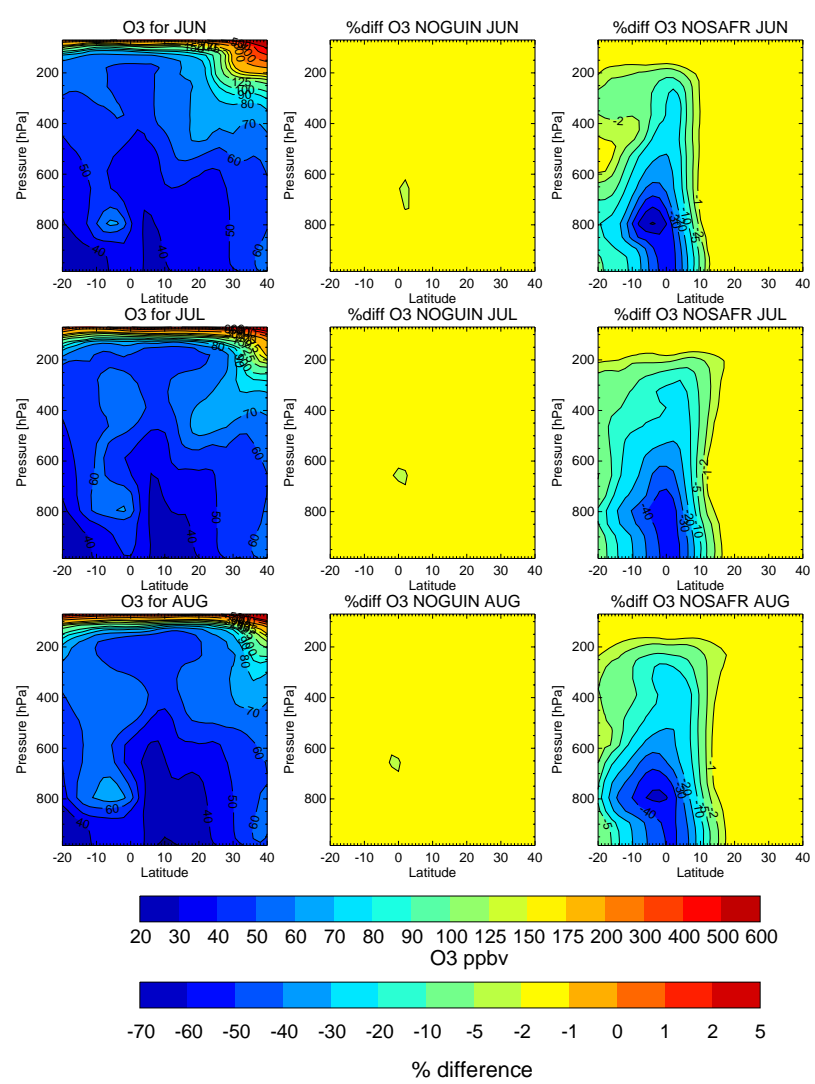

Fig. 3. As for Fig. 2 but for the mean mixing ratio of $\mathrm{O}_{3}$ given in ppbv.

For the FULL_8day simulation there is a net decrease in the emission of $\mathrm{CO}$ and $\mathrm{NO}_{\mathrm{x}}$ between $34^{\circ} \mathrm{N}-34^{\circ} \mathrm{S}$ of $\sim 10 \mathrm{Tg}$ and $\sim 0.1 \mathrm{Tg}$, respectively, when compared to the FULL simulation and integrating over all longitudes. Approximately half of this difference is associated with the African Continent. Even though the annual emission totals are the same between inventories, analysing specific seasons in a fixed region can result in differences as a result of the more rapid variability in the 8-day inventory. Moreover, due to the 8-day inventory being applied globally these differences in the emission totals also include the variability in $\mathrm{BB}$ in South America, parts of India and Indonesia. Comparing the corresponding monthly mean mixing ratios between the FULL simulation and both the FULL_8day and HIGH_IH simulations (not shown) reveals that differences are typically limited to a few percent for both trace species and change throughout JJA. The exception is for the FULL_8day simulation during July and August where $~ 5 \%$ increases occur between $5^{\circ} \mathrm{S}-5^{\circ} \mathrm{N}$ in the LT and MT. Thus altering the temporal resolution of the $\mathrm{BB}$ emission inventory exerts a more significant effect. For brevity we refer the reader to the next section where we show direct comparisons between the two simulations and to Sect. 4, where further analyses are provided.

\subsection{Variation in the daily mean between $20^{\circ} \mathrm{N}$ and $20^{\circ} \mathrm{S}$}

Figure 4a shows Hovmöller diagrams of the daily mean mixing ratios of $\mathrm{CO}$ and $\mathrm{O}_{3}$ along the 2-D north-south transect for the FULL simulation during JJA at $\sim 650 \mathrm{hPa}$. This corresponds with the altitude to where the largest variability occurs in the $\mathrm{CO}$ and $\mathrm{O}_{3}$ observations (see Sect. 4). Each daily mean is an average taken between $3^{\circ} \mathrm{W}-6^{\circ} \mathrm{E}$. This illustrates the intermittent character of $\mathrm{CO}$ and $\mathrm{O}_{3}$ around EA in the 2-D transect during the WAM in 2006. Figure $4 \mathrm{~b}$ shows the corresponding percentage differences for $\mathrm{CO}$ (top) and $\mathrm{O}_{3}$ (bottom) for the NOGUIN, NOSAFR, FULL_8day and HIGH_IH as compared with the FULL run. Again the NOSAFR run shows the largest decreases and demonstrates unambiguously that $\mathrm{BB}$ emissions from southern Africa are principally responsible for the large daily fluctations seen in Fig. 4a between $10^{\circ} \mathrm{N}-10^{\circ} \mathrm{S}$. This is in agreement with previous findings in the literature regarding the seasonal effects of BB on this region (e.g. Sauvage et al., 2006). Moreover, the influence of southern African BB above EA becomes more marked as the season progresses, where the northern edge of the burning region moves towards the Equator.

For the simulation which adopts the GFEDv2 8-day inventory (FULL_8day) the magnitude of the effect changes throughout the season. For instance, decreases of $\sim 10$ 20\% occur between 4-14 June (JD 155-165) around the Equator and $\sim 5-10 \%$ between 29 July-3 August (JD 210 215 ) around $10-20^{\circ} \mathrm{S}$, whereas increases of $\sim 5-10 \%$ occur between 9-28 July (JD 190-209) around 0-10 $0^{\circ}$ S. For the HIGH_IH run there are generally variations throughout the 2$\mathrm{D}$ transect of a few percent. Thus, the results presented here agree with the conclusions of Chen et al. (2009) in that increasing the temporal resolution of emissions from monthly to 8-day averages exerts a larger regional influence than altering the vertical distribution.

A composite of $\mathrm{CO}$ in the 2-D transect assembled from the Measurements Of Pollution In The Troposphere (MOPITT) instrument is shown in Fig. 6 in Reeves et al. (2010). Here an average compiled between 20 July-21 August (JD 201-233) is used to provide enough data coverage for the region between $2-22^{\circ} \mathrm{N}$ and $9^{\circ} \mathrm{W}-7^{\circ} \mathrm{E}$. The observations show that there is a decreasing gradient in $\mathrm{CO}$ when moving northwards away from the Equator, from $\sim 150-175 \mathrm{ppbv}$ between $2-6^{\circ} \mathrm{N}$ to $\sim 50-100 \mathrm{ppbv}$ between $12-20^{\circ} \mathrm{N}$ across the entire range of longitudes. When comparing the 2006 MOPITT values against a multi-year average of MOPITT data for the region, the $\mathrm{CO}$ mixing ratios are $\sim 60 \mathrm{ppbv}$ higher towards the equator and $\sim 10 \mathrm{ppbv}$ higher around $20^{\circ} \mathrm{N}$ (Reeves et al., 2010). There are very few MOPITT observations between $6-12^{\circ} \mathrm{N}$ and, thus, no values directly above Cotonou and most of the AMMA measurement region. Comparing the distribution of CO shown for the FULL simulation in Fig. 4a with the MOPITT composite in Reeves et al. (2010) reveals that between $2-6^{\circ} \mathrm{N}$ the model generally underpredicts $\mathrm{CO}$ by $\sim 50 \mathrm{ppbv}$. This provides evidence that northerly transport 


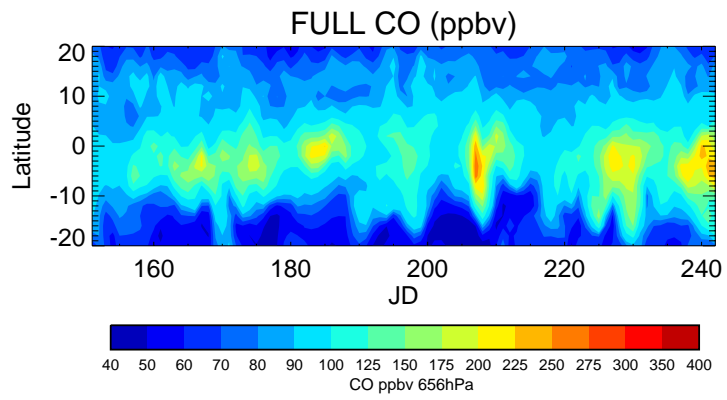

FULL O3 (ppbv)

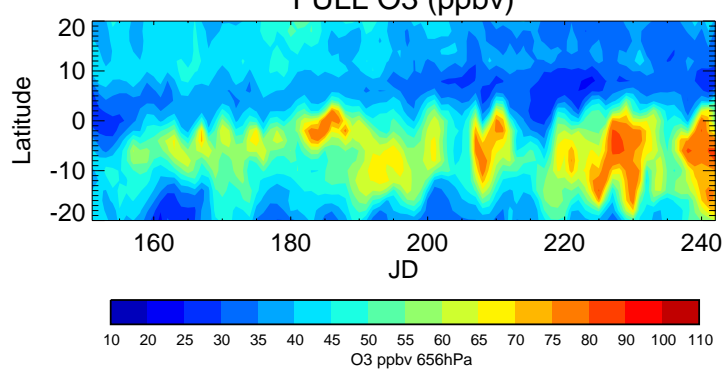

Fig. 4a. Hovmöller diagrams of the daily mean mixing ratios for $\mathrm{CO}$ (top) and $\mathrm{O}_{3}$ (bottom) in the FULL simulation along the 2-D transect averaged between $3^{\circ} \mathrm{W}-6^{\circ} \mathrm{E}$. The level shown corresponds to $\sim 650 \mathrm{hPa}$.

of $\mathrm{CO}$ across the equator from $\mathrm{BB}$ in southern Africa is not adequate in TM4_AMMA in the MT. One contributing factor is that the ECMWF operational analysis places the AEJ-S too far south as shown in Agusti-Panareda et al. (2010). For the FULL_8day and HIGH_IH simulations, the percentage differences shown in Fig. $4 \mathrm{~b}$ equate to differences of between 5-10 ppbv $\mathrm{CO}$ between $2-6^{\circ} \mathrm{N}$ compared to the FULL simulation. Therefore, the discrepancy between the modelled and measured values is not accounted for by altering either the temporal resolution or the injection height of $\mathrm{BB}$ emissions.

Figures 5 and 6 show the variability in the daily mean mixing ratio between the various sensitivity simulations for these two trace gas species and the passive tracers. Two locations are chosen: $4-6^{\circ} \mathrm{S}$ and $6-8^{\circ} \mathrm{N}$ at $\sim 860 \mathrm{hPa}$ and $\sim 655 \mathrm{hPa}$, respectively. The latitudinal position of these two cells in the 2-D transect is indicated as filled red sections in Fig. 1. The southerly cell was selected to correspond to where the maximal concentrations for both $\mathrm{CO}$ and $\mathrm{O}_{3}$ occur (as shown in Figs. 2 and 3) i.e. 4-6 $6^{\circ}$, and so as to be directly over the Cotonou measurement site from which ozonesondes were launched (cf. Fig. 1). The northerly cell corresponds to the position where selected flights took place during the AMMA measurement campaign (i.e. $6-8^{\circ} \mathrm{N}$ ). The two altitudes which are chosen are representative of the LT and the MT, where low and "extreme" $\mathrm{O}_{3}$ episodes were observed, respectively (Thouret et al., 2009).

A high correlation is seen between the variability in the southern Africa passive tracer (SAfr) and CO for both locations between Julian Days (JD) 191-240, where a "pulsing"
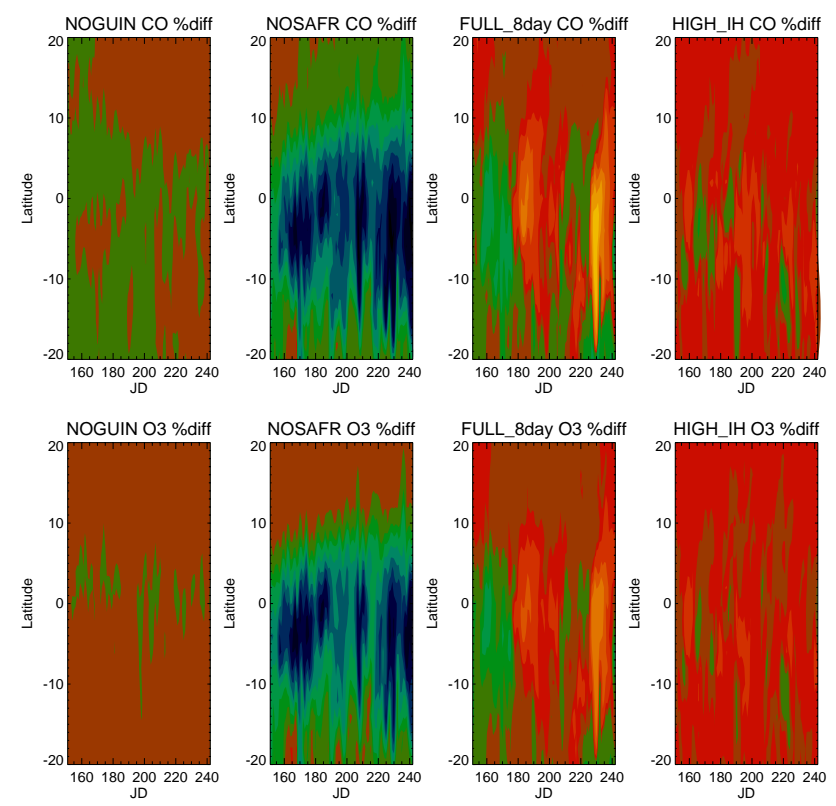

Fig. 4b. The percentage differences in the daily mean mixing raios of (top row) $\mathrm{CO}$ and (bottom row) $\mathrm{O}_{3}$ as compared with the FULL run. The differences are calculated as (SENS-FULL)/FULL $\times 100$. The level shown corresponds to $\sim 650 \mathrm{hPa}$.

effect occurs due to variations in the transport of air from southern Africa. Moreover, the "break" period identified by Mari et al. (2008) can also be clearly seen in the mixing ratios for CO and SAfr between 3-8 August (JD 215-220), where the westerly transport from southern Africa stops periodically. Interestingly other periods where westerly transport diminishes in the lower troposphere can also be seen e.g. during July (JD 183-191). Moreover, Fig. 5 shows that for $\mathrm{O}_{3}$ increases in the daily mean values of $\sim 10 \mathrm{ppbv}$ occur between $4-6^{\circ} \mathrm{S}$ as the season progresses. For the northerly cell the opposite occurs. Comparing the FULL simulation with the FULL_8day shows that for both trace species higher (lower) concentrations are seen in the FULL run for June (August) at $4-6^{\circ} \mathrm{S}$, the latitude band which is influenced more by the BB emissions. Finally, for the HIGH_CO simulation it can be seen that a significant increase in the mixing ratio of $\mathrm{CO}$ occurs at both locations during July and $\mathrm{Au}-$ gust. This increase extends into West Africa $\left(6-8^{\circ} \mathrm{N}\right)$, where an increase in the background concentration occurs in the LT (see Sect. 4.2). Although increasing the CO emission from southern $\mathrm{BB}$ does reduce the relative differences between TM4_AMMA and the MOPITT measurements shown in Reeves et al. (2010), it fails to capture the correct gradient across the equator. 

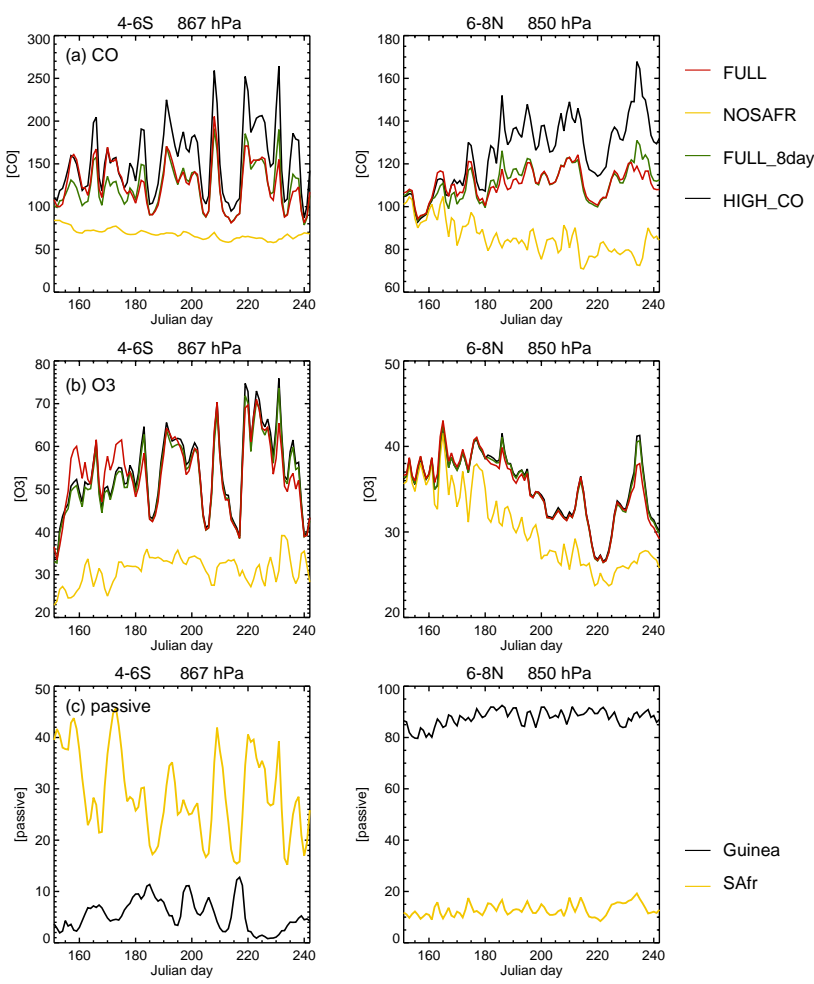

Fig. 5. Daily mean values of mixing ratios of $\mathrm{CO}$ (top), $\mathrm{O}_{3}$ (middle) and the Guinea and SAfr passive tracers (bottom) averaged between $3^{\circ} \mathrm{W}-6^{\circ} \mathrm{E}$ for season JJA between $4-6^{\circ} \mathrm{S}$ (left) and 6-8 $8^{\circ} \mathrm{N}$ (right) at $\sim 860 \mathrm{hPa}(\sim 1.5 \mathrm{~km}$ height). For the trace gases the colour key is thus; FULL (red), NOSAFR (yellow), FULL_8day (dark green) and HIGH_CO (black), given in ppbv. For the passive tracers Guinea (black) and southern Africa (yellow) are given in pptv.

\section{A comparison between model results and observations}

Here we compare co-located model output against a variety of different in-situ measurements taken in the troposphere in EA and southern Africa during the period of interest. The aim is to assess possible short-comings in the model performance for Africa near source regions and for locations influenced by long-rang transport of BB plumes, as well as to investigate whether the daily and monthly variability can be captured with a large-scale global CTM. Moreover, we also assess whether the modifications to the model with respect to BB emissions improve the agreement with the chosen measurement data.

\subsection{Regional comparisons in southern Africa}

Figure 7 shows monthly mean comparisons of the mixing ratios of tropospheric $\mathrm{CO}$ from the surface to $\sim 300 \mathrm{hPa}$ between the MOZAIC measurements taken at Windhoek, Namibia, and the FULL, NOGUIN and NOSAFR simula-
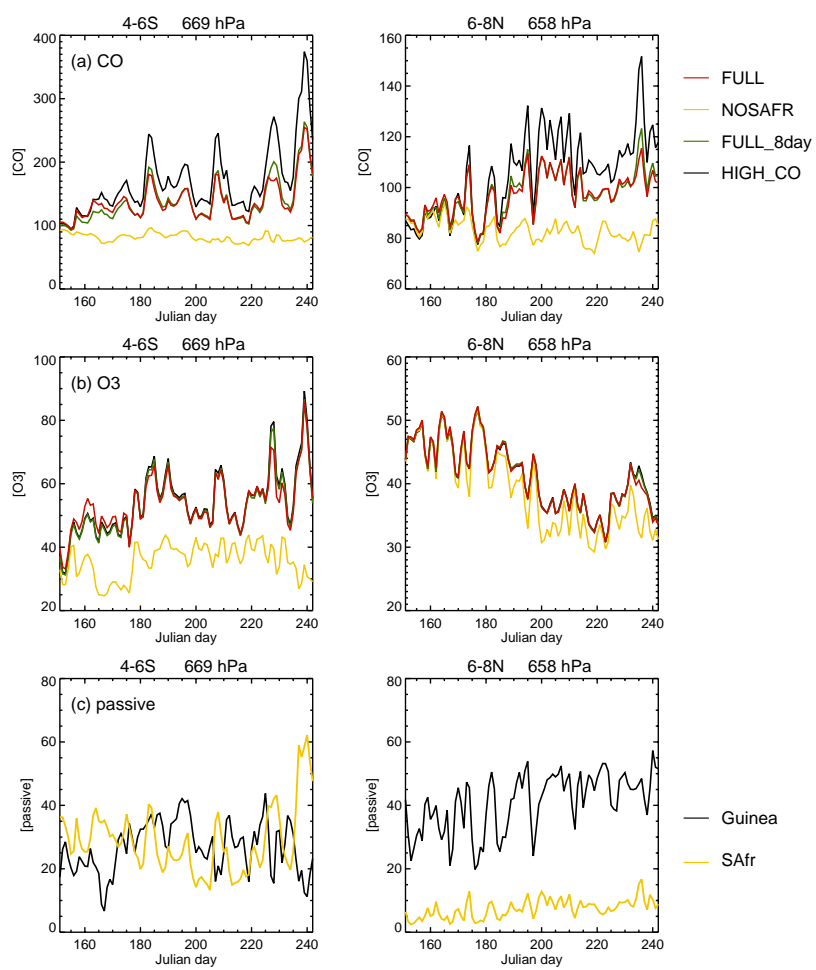

Fig. 6. Same as Fig. 5, but at $\sim 670 \mathrm{hPa}(\sim 3.3 \mathrm{~km}$ height $)$.

tions for June, July and August, where all simulations shown use the GFEDv2 monthly inventory. Comparing the standard deviation from the measurements (green lines) for each month shows that the variability of CO in the LT and MT increases as the regional $\mathrm{BB}$ activity increases through the season. The comparison to model results shows that there is generally a significant under prediction of tropospheric $\mathrm{CO}$ at Windhoek by TM4_AMMA. Examining the NOSAFR run shows that emissions from regional BB sources account for $\sim 40-50 \%$ of the CO in the LT at Windhoek, meaning 50 $60 \%$ occurs as a result of either other emission sources (e.g. nearby urban centers), in-situ chemical formation (e.g. photolysis of formaldehyde) and long-range transport (e.g. from South America).

Figure 8 shows comparisons of the weekly variability in the mixing ratios of tropospheric $\mathrm{CO}$ at 500, 650, 750 and $850 \mathrm{hPa}$, respectively, between the measurements and the FULL, FULL_8day, HIGH_IH and HIGH_CO simulations. It can be seen that there is generally a $\sim 10 \%$ variability in $\mathrm{CO}$ between consequetive weeks throughout JJA at all altitudes. Comparing simulations shows that increasing the temporal resolution of the BB emissions in TM4_AMMA results in larger differences than those introduced by modifying the vertical distribution of the emissions, as seen when comparing the various simulations for the outflow region (cf. Fig. 4b). Comparing the FULL and FULL_8day values 

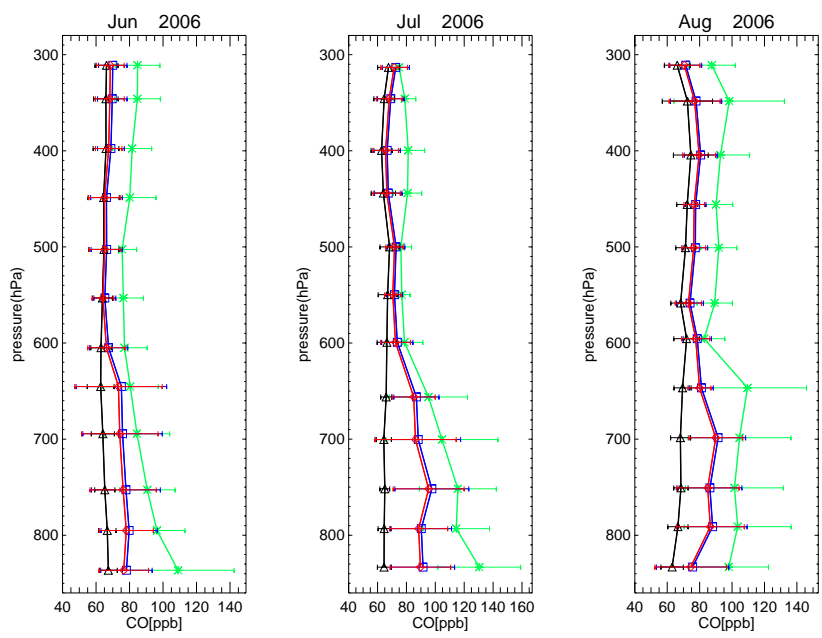

Fig. 7. Comparisons of monthly mean tropospheric profiles for $\mathrm{CO}$ taken at Windhoek in Namibia $\left(22.5^{\circ} \mathrm{S}, 17.5^{\circ} \mathrm{E}\right)$ against colocated model output from TM4_AMMA for JJA during 2006. The mean values from the measurements, and their standard deviations, are shown in green. The results of six different simulations are shown. The colour scheme is thus: FULL (blue), NOGUIN (red) and NOSAFR (black) simulations.

shows that for August there is a degradation in the quality of the simulations when using the GFEDv2 8-day BB inventory resulting in less $\mathrm{CO}$ for some weeks. Moreover, the degradation seen for the FULL_8day simulation in the LT during July does not affect the MT, whereas the opposite is true during August. This suggests that the degredation in August is due to less $\mathrm{CO}$ being transported into the MT rather than a local BB event. The HIGH_IH simulation shows that altering the injection height has little effect near the source. For the HIGH_CO simulation, which adopts the GFEDv2 8-day BB inventory, increases occur in the LT which generally improve the comparisons. To investigate the effect of horizontal resolution and the update frequency of the ECMWF meterological fields an additional comparison was performed using the output from the TM5 model (Huijnen et al., 2010) ran in zoomed mode $\left(1^{\circ} \times 1^{\circ}\right)$ over Africa using 3 hourly ECMWF meteorological data and the 8-day inventory (not shown). No significant improvement in the quality of the comparison occurred for these months (V. Huijnen, personal communication, 2009). Thus, coarsening of the BB emission inventory and choosing a 6-hourly update frequency of ECMWF meterology are not dominant factors towards the disagreement shown in Fig. 8. In summary, the improvements shown in the comparisons of the tropospheric profiles for the HIGH_CO run provide strong evidence that the emission of $\mathrm{CO}$ in southern Africa is too low during 2006 in the GFEDv2 emission inventory.

When performing similar comparisons against the corresponding tropospheric $\mathrm{O}_{3}$ profiles from the MOZAIC database the agreement is much better (cf. Fig. 8 in Williams
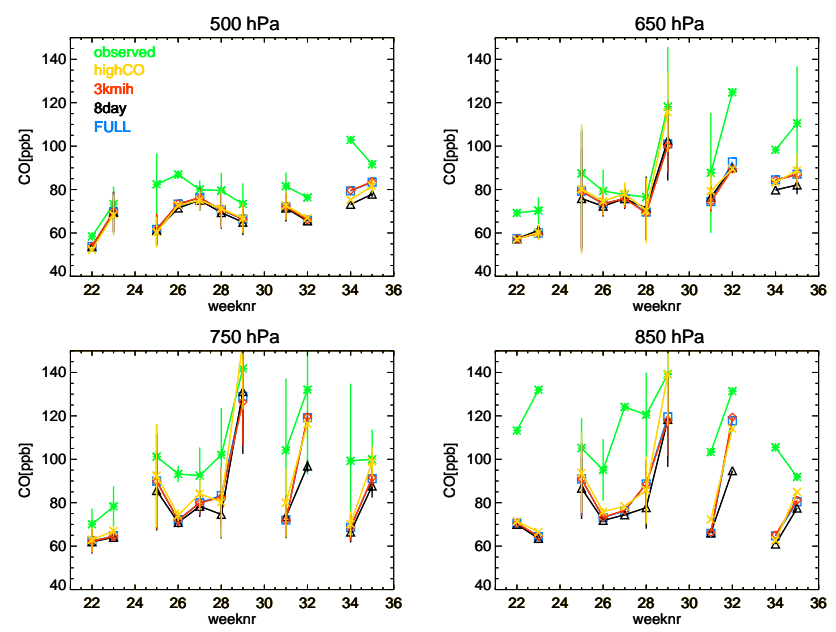

Fig. 8. Comparisons of weekly mean tropospheric $\mathrm{CO}$ values measured at $500 \mathrm{hPa}, 650 \mathrm{hPa} 750 \mathrm{hPa}$ and $850 \mathrm{hPa}$ above Windhoek in Namibia $\left(22.5^{\circ} \mathrm{S}, 17.5^{\circ} \mathrm{E}\right)$ against co-located model output from TM4_AMMA for JJA during 2006. The mean values from the measurements, and their standard deviations, are shown in green. The results of four different simulations are shown. The colour scheme is thus: FULL (blue), FULL_8day (black), HIGH_IH (red) and HIGH_CO (yellow) simulations. The vertical bars represent the standard deviation of the mean.

et al., 2009a). For all months during JJA, the NOSAFR run underpredicts tropospheric $\mathrm{O}_{3}$ mixing ratios in the LT by $\sim 5 \mathrm{ppbv}$ ( $\sim 15 \%$ of that which is measured), whereas the FULL simulation tends to over predict for July and August by $5-10 \mathrm{ppbv}$, although the profile shape is captured quite well. Comparing the FULL_8day simulation shows that there is only a marginally better agreement with the observations. Although the agreement for $\mathrm{O}_{3}$ is also dependent on the chemical mechanism employed, this suggests that for $\mathrm{NO}_{\mathrm{x}}$ the BB emission estimates provided in the GFEDv2 inventory are rather good for 2006. For the other sensitivity studies no significant differences occur compared to the FULL_8day run, apart from slight increases between $600-700 \mathrm{hPa}$ in the HIGH_IH.

The paucity of measurements in southern Africa significantly hampers the ability of assessing model performance. Although there are a host of satellite measurements available for selcted periods their low sensitivity to the LT and limited sampling frequency typically mask short term variability in surface concentrations. This emphasises the need for an expansion of the network of ozonesoundings, initiation of ground-based measurements for e.g. CO or continuation (expansion) of the MOZAIC flight network within the tropics. Such measurements can be used to constrain the inter-annual variability in $\mathrm{BB}$ emissions from southern Africa, investigate seasonal trends in tropospheric $\mathrm{O}_{3}$ and aid e.g. the retrieval of total tropical ozone columns (e.g. de Laat et al., 2009). 

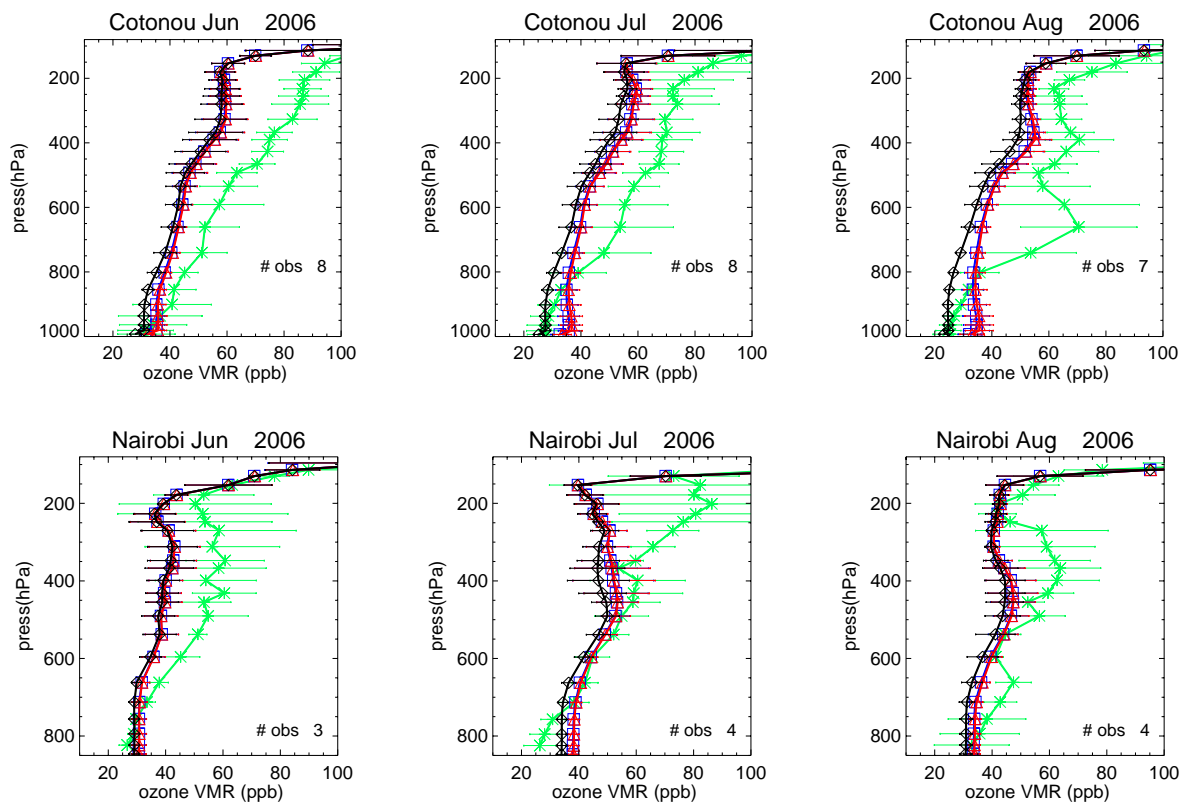

Fig. 9. Comparisons of monthly mean tropospheric radio sonde profiles for $\mathrm{O}_{3}$ (green lines) taken at Cotonou, Nigeria $\left(6.2^{\circ} \mathrm{N}, 2.2^{\circ} \mathrm{E}\right.$ ) and Nairobi, Kenya $\left(1.3^{\circ} \mathrm{S}, 36.8^{\circ} \mathrm{E}\right)$ against co-located model output from TM4_AMMA for June, July and August 2006. The number of measurements used for calculating each monthly mean are given within each panel. The results of three different simulations are shown: FULL (blue), NOGUIN (red) and NOSAFR (black). The horizontal bars represent the standard deviation of the mean.

\subsection{Regional comparisons in Equatorial Africa}

Figure 9 shows comparisons of the monthly mean profiles of tropospheric $\mathrm{O}_{3}$ from radio sonde measurements at both Cotonou $\left(6.2^{\circ} \mathrm{N}, 2.2^{\circ} \mathrm{E}\right)$ and Nairobi $\left(1.3^{\circ} \mathrm{S}, 36.8^{\circ} \mathrm{E}\right)$ against co-located model output for the FULL, NOGUIN and NOSAFR simulations. The comparisons for Cotonou show that, whilst overestimating the surface concentrations, TM4_AMMA has difficulty in simulating the observed increase in $\mathrm{O}_{3}$ with altitude, leading to underpredictions of $\sim 30-40 \%$ at between $600 \mathrm{hPa}$ and the tropopause. Figure 9 also shows that the increase in the MT observed by the sondes is not captured well by TM4_AMMA. Comparing the NOGUIN profile at Cotonou with the observations shows that the effect of regional BB activity between 0 $10^{\circ} \mathrm{N}$ on the tropospheric $\mathrm{O}_{3}$ profile is insignificant during the WAM, whereas comparing the corresponding NOSAFR profile shows a reduction in tropospheric $\mathrm{O}_{3}$ below $800 \mathrm{hPa}$ of $\sim 30-40 \%$. This indicates that the transport determined by the ECMWF meteorology does not introduce polluted air from southern Africa directly into the MT at this latitude but rather into the LT, as shown in Figs. 5 and 6. Finally, an additional comparison was again performed against output from the TM5 model in zoomed mode $\left(1^{\circ} \times 1^{\circ}\right)$ using 3 hourly ECMWF meteorological data and the GFEDv2 8day inventory. As for the regional MOZAIC comparisons, no significant improvement in model performance occurred at Cotonou in the MT (V. Huijnen, personal communica- tion, 2009). This suggests that the deficiency in transport in TM4_AMMA is not due to abrupt changes in circulation which are missed as a result of using 6 hourly meteorological fields.

To assess whether the model can capture the vertical distribution of $\mathrm{O}_{3}$ in the LT and MT in EA at a location nearer the active $\mathrm{BB}$ regions we also show comparisons for Nairobi. For this location the monthly mean model profiles exhibit a better agreement with the measurements, especially for July and August in the LT to MT, where the sampling frequency at Nairobi is lower than at Cotonou for this season. However, the variability in the ozonesonde measurements in the LT and MT is also much lower than at Cotonou as shown by comparing the magnitude of the standard deviation associated with the monthly means for both sites. This has also been observed in the MOZAIC climatology when comparing the monthly means taken from Lagos and Nairobi (Sauvage et al., 2005). Interestingly, the largest increase in $\mathrm{O}_{3}$ during August occurs much higher up in the troposphere, between $300-400 \mathrm{hPa}$, suggesting an intrusion of air rich in $\mathrm{O}_{3}$ from the subtropical jet stream (e.g. Zachariasse et al., 2000). There is also a separate peak in the LT around $700 \mathrm{hPa}$. Comparing the NOSAFR profile reveals that the effect of regional BB close to the launch site is limited to a few ppbv ( $\sim 5$ $10 \%$ ) when adopting the GFEDv2 monthly emission inventory. The quality of the comparison at Nairobi provides some confidence that TM4_AMMA does not exhibit an underestimation in $\mathrm{MT} \mathrm{O}_{3}$ in east Africa as shown for West Africa. 
Table 2. Pearson's correlation co-efficients between modeled and measured values of $\mathrm{CO}$ over Equatorial Africa in the lower troposphere below $800 \mathrm{hPa}$ during July and August 2006.

\begin{tabular}{lrrrrr}
\hline Name of Run & $4-6^{\circ} \mathrm{N}$ & $6-8^{\circ} \mathrm{N}$ & $8-10^{\circ} \mathrm{N}$ & $10-15^{\circ} \mathrm{N}$ & $15-20^{\circ} \mathrm{N}$ \\
\hline FULL & 0.622 & 0.021 & -0.054 & -0.072 & -0.335 \\
FULL_8day & 0.622 & 0.021 & -0.069 & -0.065 & -0.334 \\
HIGH_IH & 0.622 & 0.021 & -0.063 & -0.075 & -0.338 \\
NOSAFR & 0.827 & 0.084 & -0.085 & 0.027 & -0.454 \\
\hline
\end{tabular}

Comparing the FULL_8day, HIGH_IH and HIGH_CO simulations at both measurement sites reveals no significant improvement in model performance (not shown), even though the location of the Nairobi sounding is within the $\mathrm{SH}$, similar to the MOZAIC comparisons. For Cotonou this is due to the differences of only a few percent between simulations not having any appreciable effect as far north as the measurement site. For Nairobi this is due to the regional $\mathrm{BB}$ activity being rather low and that BB plumes from Central Africa are typically transported westwards away from the measurement site.

Figure 10 shows a comparison of co-located $\mathrm{CO}$ output from the FULL and NOSAFR simulations against a composite of in-situ Aircraft measurements made during the intensive AMMA measurement campaign in July and August 2006 around EA. It can be seen that, apart from a few instances, the mixing ratios for $\mathrm{CO}$ typically range between 90-150 ppbv in both the LT and MT. The highest mixing ratios (>270 ppbv) occur in the MT around $4-7^{\circ} \mathrm{N}$, which are attributed to BB plumes (Reeves et al., 2010). There are also a few flights which measure high $\mathrm{CO}$ mixing ratios in the boundary layer. Analysing the FULL simulation shows that TM4_AMMA fails to capture these high values in the MT around $4-7^{\circ} \mathrm{N}$, whilst overestimating CO in the LT and MT by $50-60 \mathrm{ppbv}$ around $10-15^{\circ} \mathrm{N}$. The instances of high $\mathrm{CO}$ between $150-300 \mathrm{hPa}$ are also not captured in the model suggesting that either the convective uplift from southern Africa is too weak (Williams et al., 2009a) or there is a missing component introduced by long range transport in the upper troposphere from e.g. India. The corresponding plot for the NOSAFR simulation shows that the overestimation in the LT and MT is predominantly due to BB from southern Africa, which causes high background values. Thus in TM4_AMMA BB plumes originating from e.g. $25-30^{\circ} \mathrm{E}$ are transported directly into Guinea in the LT. We expand on this further in Sect. 5.

Table 2 provides Pearson's correlation co-efficients between the $\mathrm{CO}$ observations from the AMMA composite and the corresponding output from the FULL, FULL_8day, HIGH_IH and NOSAFR simulations for the LT below $800 \mathrm{hPa}$. It can be seen that moving from $4-20^{\circ} \mathrm{N}$ the correlation between the model and the measurements generally
Table 3. Pearson's correlation co-efficients between modeled and measured values of $\mathrm{CO}$ over Equatorial Africa in the middle troposphere between 500-800 hPa during July and August 2006.

\begin{tabular}{lrrrrr}
\hline Name of Run & $4-6^{\circ} \mathrm{N}$ & $6-8^{\circ} \mathrm{N}$ & $8-10^{\circ} \mathrm{N}$ & $10-15^{\circ} \mathrm{N}$ & $15-20^{\circ} \mathrm{N}$ \\
\hline FULL & 0.381 & 0.470 & 0.825 & 0.168 & 0.123 \\
FULL_8day & 0.383 & 0.439 & 0.838 & 0.150 & 0.125 \\
HIGH_IH & 0.357 & 0.470 & 0.822 & 0.279 & 0.121 \\
NOSAFR & 0.482 & 0.571 & 0.653 & 0.228 & 0.045 \\
\hline
\end{tabular}

becomes worse for all the chosen simulations. Between 6$15^{\circ} \mathrm{N}$ there is little correlation between the model and the measurements for all sensitivity studies. Between $15-20^{\circ} \mathrm{N}$ the model generally exhibits a weak anti-correlation with the measurements, where the presence of $\mathrm{CO}$ from $\mathrm{BB}$ in southern Africa does reduce the anti-correlation somewhat. No significant improvement in the correlation co-efficient occurs for either the FULL_8day and HIGH_IH simulations.

Table 3 shows the corresponding Pearson's correlation coefficients for the MT between 500-800 hPa. Here the model tends to correlate better with the measurements than in the LT for all of the chosen sensitivity studies, where the correlation increases when travelling northwards from $6-10^{\circ} \mathrm{N}$. The correlation then drops markedly between $10-20^{\circ} \mathrm{N}$, partially due to large amounts of $\mathrm{CO}$ being transported from southern Africa into the region. The influence of altering the approach used for introducing BB into TM4_AMMA shows that, in general, the FULL_8day run results in the best correlation in the MT across all simulations in $50 \%$ of the latitude regions.

To provide further insight as to why TM4_AMMA has difficulty in capturing the high $\mathrm{CO}$ measured in the MT around $4-7^{\circ} \mathrm{N}$ we present comparisons along a flight track where these values occurred. The top panels of Figure. 11 show comparisons of tropospheric $\mathrm{CO}$ and $\mathrm{O}_{3}$ measured in-situ on board of the BAe-146 aircraft during a flight on 13 August 2006 with co-located model output and the altitude at which the measurements were made. The bottom panels show the corresponding flight track of the aircraft, where the colour scale shows the magnitude of the mixing ratios to indicate the location where the extreme events for both trace gases occur. It can be seen that during this day the aircraft encountered an air mass with very high mixing ratios of $\mathrm{CO}$ and $\mathrm{O}_{3}$ near the coast ( $>200 \mathrm{ppbv}$ and $>100 \mathrm{ppbv}$, respectively) at about $08: 50 \mathrm{~h}$ on the southward flight segment (at $\sim 3.5 \mathrm{~km}$ ) and at about 10:00 h on the return northward flight segment (at $\sim 2.5 \mathrm{~km}$ ). These plumes were encountered at similar altitudes to where the maximum $\mathrm{O}_{3}$ concentrations were seen in the sondes (cf. Fig. 9), and thus suggests the same origin. The large concentrations in both species suggest an aged BB plume, where the photochemical processing of the polluted air has formed $\mathrm{O}_{3}$ during the previous days (Jost et al., 2003). Moreover, corresponding acetonitrile measurements, 

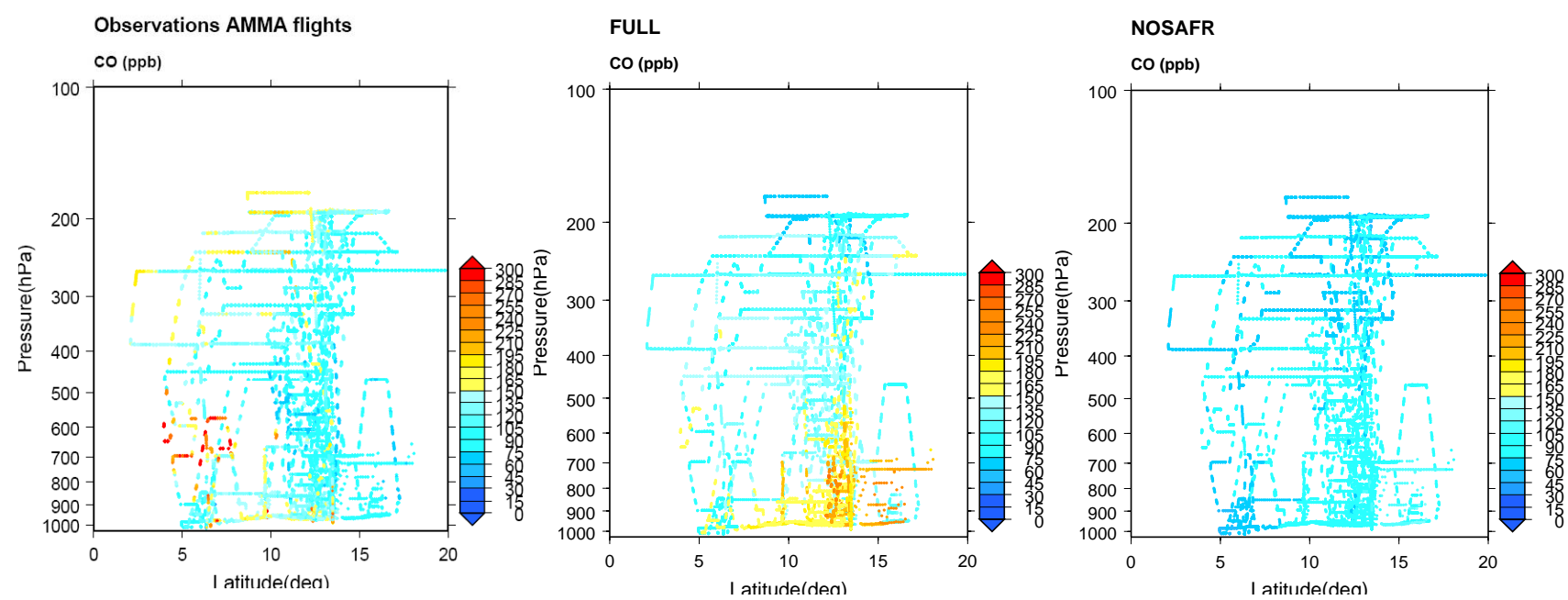

Fig. 10. Comparisons of tropospheric CO measured during the AMMA measurement campaign on the F-20 falcon, German Falcon (D-20), ATR and BAe-146 against TM4_AMMA output for July and August 2006. The three composites correspond with measurements (left), the FULL simulation (middle), and the NOSAFR simulation (right).

which act as a "marker" for BB, also show associated increases (Reeves et al., 2010). All of the sensitivity runs fail to capture this enhancement except the NOSAFR run, whose relative increases are of the order of $\sim 10-20 \%$ compared to the $\sim 200-300 \%$ increases observed. For the majority of sensitivity studies there appears to be an anti-correlation for both $\mathrm{CO}$ and $\mathrm{O}_{3}$ between the model and measurements during these particular events. Examining the NOSAFR run at $08: 50 \mathrm{~h}$ shows that at high altitudes there is an additional source of $\mathrm{O}_{3}$ compared to $\mathrm{CO}$. This is most probably from long range transport of $\mathrm{O}_{3}$ by the AEJ-N in the MT as discussed in Sauvage et al. (2007) for JJA.

For locations further inland, e.g. before $08: 15 \mathrm{~h}$ and after 10:15 h, there is an anti-correlation between $\mathrm{CO}$ and $\mathrm{O}_{3}$ in the observations. The corresponding acetonitrile signature is low (not shown) indicating air-masses which are more representative of the background. The agreement of all simulations with the observations improves, especially for $\mathrm{CO}$, but there tends to be an overestimation for $\mathrm{O}_{3}$ at low altitudes. Possible reasons include an underestimation in dry deposition over vegetated areas, and/or the use of climatological soil $\mathrm{NO}_{\mathrm{x}}$ emissions (Williams et al., 2009a). Again, the exception is the NOSAFR simulation, which shows that BB from southern Africa has a large influence on the tropospheric background between $8-10^{\circ} \mathrm{N}$ and introduces a significant fraction for $\mathrm{CO}$ via long range transport (cf. Fig. 10). Considering that additional biogenic production of $\mathrm{CO}$ from e.g. the oxidation of methanol is not included in the model implies that there is generally an overestimation of the background (see below). For $\mathrm{O}_{3}$ the contribution from $\mathrm{BB}$ in southern Africa is typically $\sim 20-30 \%$. In part this is due to less in-situ $\mathrm{O}_{3}$ formation due to lower concentrations of $\mathrm{O}_{3}$ pre-cursors such as PAN being transported into the region (not shown).
Next we focus on a flight more representative of the background over EA. Figure 12 shows a corresponding comparison for the measurements taken on the 14 August. Comparing the location of the flight tracks it can be seen that the flight path is quite similar to that of the 13 August, apart from the latitudinal range covered, which is much smaller. Moreover, the background mixing ratios of $\mathrm{CO}$ and $\mathrm{O}_{3}$ are also similar to the previous day, where an anti-correlation between $\mathrm{CO}$ and $\mathrm{O}_{3}$ in the measurements is again quite evident. The agreement for each of the trace species in most simulations is consistent with that shown for similar locations in Fig. 11, in that the $\mathrm{O}_{3}$ in the model is higher by $\sim 100 \%$, especially in the LT. Again the NOSAFR simulation seems to reproduce much of the variability in $\mathrm{O}_{3}$ with altitude, albeit with a smaller amplitude, i.e. the broad peaks at 05:00 h, 07:30 $\mathrm{h}$ and $08: 40 \mathrm{~h}$, which correspond with measurements made between $2-3 \mathrm{~km}$. For lower altitudes the NOSAFR run overestimates $\mathrm{O}_{3}$ and underestimates $\mathrm{CO}$ when compared to the BAe-146 measurements (see discussion above). For $\mathrm{O}_{3}$ this tends to agree with the comparisons made for Cotonou during August (cf. Fig. 9).

When comparing the other sensitivity studies it can be seen that for the FULL_8day and NOGUIN runs there is no significant improvement, as seen for the MOZAIC comparisons shown in Figs. 7 and 8, and the ozonesonde comparisons shown in Fig. 9. For the HIGH_CO run (not shown) there is a significant degradation in the quality of the comparisons with respect to $\mathrm{CO}$, as a result of the efficient transport of $\mathrm{CO}$ into the region, which increases the background $\mathrm{CO}$ by $\sim 50$ ppbv. 

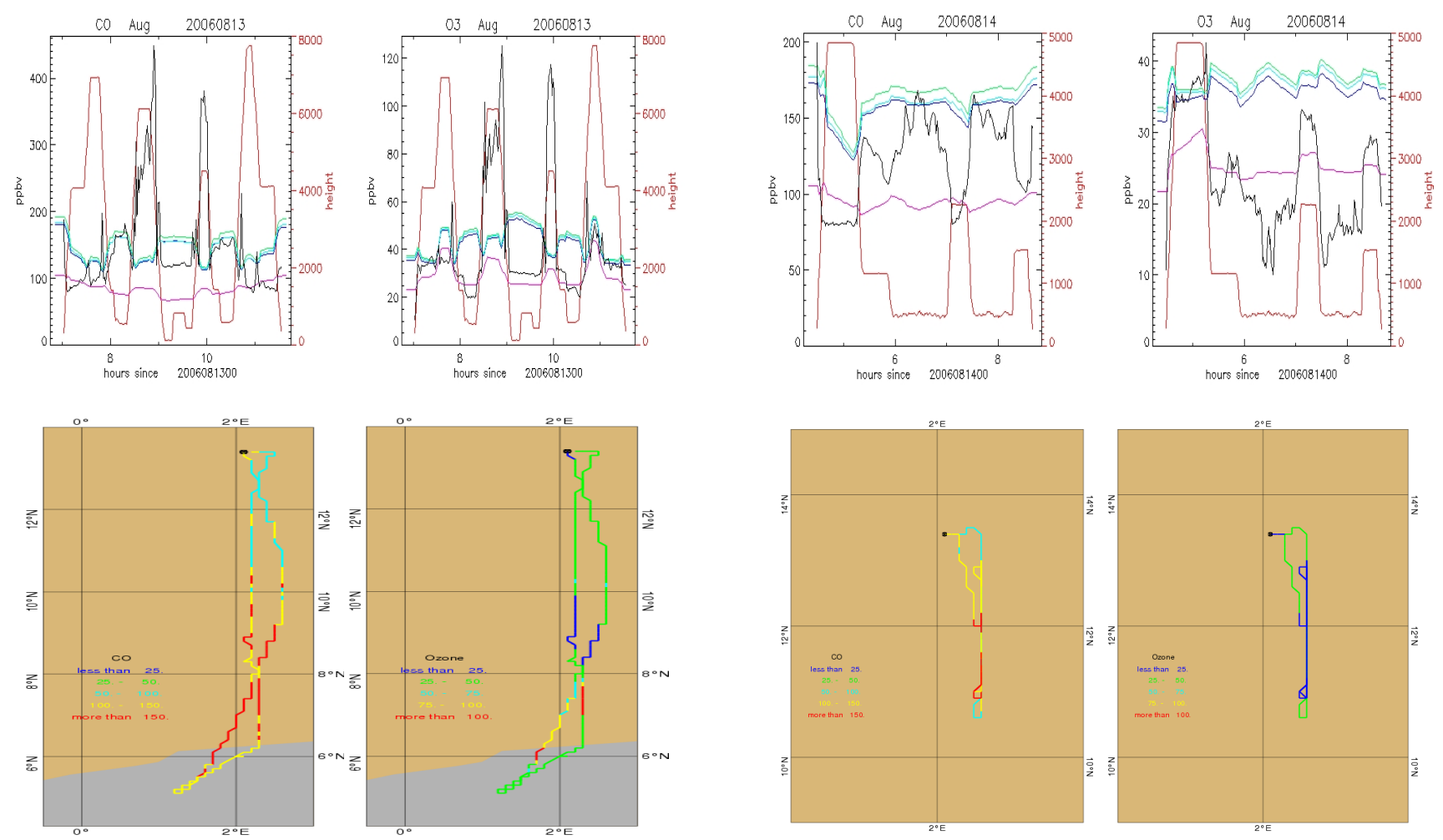

Fig. 11. Top panel: Comparisons of tropospheric CO (left) and $\mathrm{O}_{3}$ (right) measured on the BAe-146 against TM4_AMMA output on the 13 August 2006. The measurements are indicated by black lines, with results of four different simulations being shown: FULL (green), FULL_8day (cyan), NOGUIN (blue) and NOSAFR (pink). The bottom panels show the flight track of the aircraft with colour coding for the $\mathrm{CO}$ (left) and $\mathrm{O}_{3}$ measurements (right) in ppbv, respectively. The altitude of the aircraft (in $\mathrm{m}$ ) is shown as the red line in the top panel and the start/end of the flight is indicated by the black dot in the lower panel.

\section{Trajectory calculations}

The "extreme" event observed on the 13 August in both the sonde and aircraft measurements near the southern coast of West Africa suggests an air mass that has been in recent contact with BB emissions (Reeves et al., 2010). However, we have shown that the northward transport of polluted air from southern Africa is constrained to between $\sim 2-4^{\circ} \mathrm{N}$ and between $\sim 10-15^{\circ} \mathrm{N}$ for the MT in TM4_AMMA (cf. Figs. 4a and 10 , respectively). One governing factor related to the long-range transport of polluted plumes in a CTM is the meteorological analysis data which are used to drive the model. Here we present a number of 10-day trajectory calculations using the ECMWF meteorological fields which are initiated (a) in the region where the most intense BB activity occurs during August, (b) around the location at which the ozonesoundings were launched or (c) along the aircraft flight paths shown in the preceding sections. For (a) we calculate for-

Fig. 12. Comparisons of tropospheric $\mathrm{CO}$ (left) and $\mathrm{O}_{3}$ (right) measured on the BAe-146 against TM4_AMMA output on the 14 August 2006. The colour key is identical to that described for Fig. 11. The bottom panels show the corresponding location of the aircraft for which these measurements occurred.

ward trajectories to trace the fate of pollutants being transported westward out of southern Africa and for (b) and (c) we perform backward trajectories.

Figure 13 shows 10-day forward trajectory calculations initiated on the 4 August at $\sim 800 \mathrm{hPa}$ and finishing on the 14 August. The end date corresponds with the date on which the "extreme" event was observed at Cotonou. The bulk trajectories are placed in the latitude range of $10-15^{\circ} \mathrm{S}$ between $15-20^{\circ} \mathrm{E}$ and $25-30^{\circ} \mathrm{E}$, respectively, with both being initiated $1.5 \mathrm{~km}$ above the ground to account for rapid convective uplift of e.g. CO due to increased buoyancy of the burning plume. From the top panel of Fig. 13 it can be seen that, once the air-masses travel westwards, they lose altitude and travel through the LT towards the north-west. Although some do reach the southern coast of West Africa they are at a much lower altitude than the "peak" which is observed at $\sim 650 \mathrm{hPa}$ (cf. Figs. 9 and 10). This explains the NOSAFR profile shown in Figs. 5 and 6, where the effect of BB from southern Africa on $\mathrm{O}_{3}$ is largest in the LT. The bottom panel of Fig. 13 shows that the BB which occurs in Central Africa is transported northwards and lifted by convective mixing towards the equator as found in Barret et al. (2008). Additional trajectories initiated for various days during August 

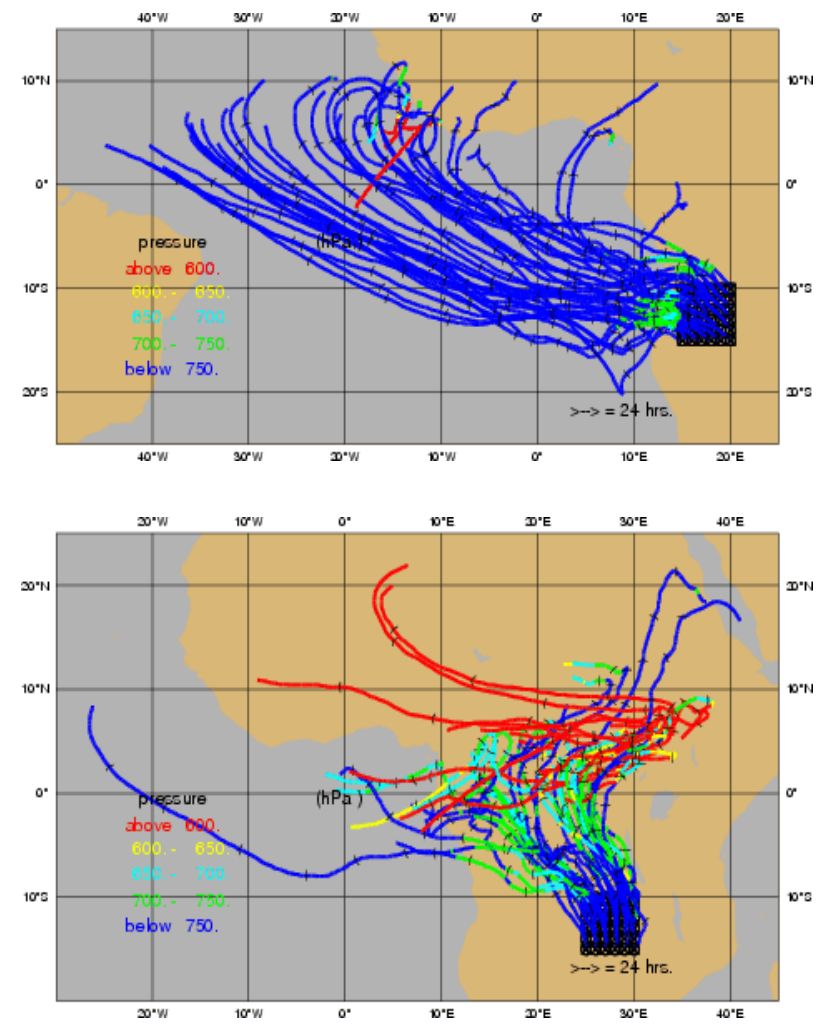

Fig. 13. Ten day forward trajectories starting from two regions in southern Africa exhibiting intense BB activity in the GFEDv2 monthly emission inventory. Separate trajectories were initiated at a distance of $1^{\circ}$ between $10-15^{\circ} \mathrm{S}$ and (top) $15-20^{\circ} \mathrm{E}$ and (bottom) $25-30^{\circ} \mathrm{E}$ on the 4 August 2006. The pressure levels through which each trajectory passes are indicated thus: $>750 \mathrm{hPa}$ (blue), 700-750 hPa (green), 650-700 hPa (cyan), 600-650 hPa (yellow) and $<600 \mathrm{hPa}$

between $0-5^{\circ} \mathrm{S}$ and $10-20^{\circ} \mathrm{E}$ (not shown) all follow a northeasterly direction and do not flow directly above West Africa. Therefore, the ECMWF meteorology predicts that air-masses which originate near regions exhibiting high $\mathrm{BB}$ activity do not travel directly into the MT around $6^{\circ} \mathrm{N}$.

Figure 14 shows 10-day back trajectory calculations starting on the 3 and 14 August at $\sim 600 \mathrm{hPa}$ from the Cotonou measurement site. These dates correspond to ozonesonde measurements that give profiles both with (14 August) and without (3 August) an enhancement in $\mathrm{MT} \mathrm{O}_{3}$ (Mari et al., 2008; Thouret et al., 2009). It can be seen that there are distinct differences between the air-mass histories on these two days. For the 3 August the air at this altitude originates from either the LT in the Gulf of Guinea or from the Saharan region to the north. For the 14 August the air at $\sim 600 \mathrm{hPa}$ originates to the west of the measurement site, where it passes over eastern Nigeria a few days prior to reaching Cotonou. The enhanced MT $\mathrm{O}_{3}$ observed in the sondes is due to the northerly transport of BB polluted plumes from southern
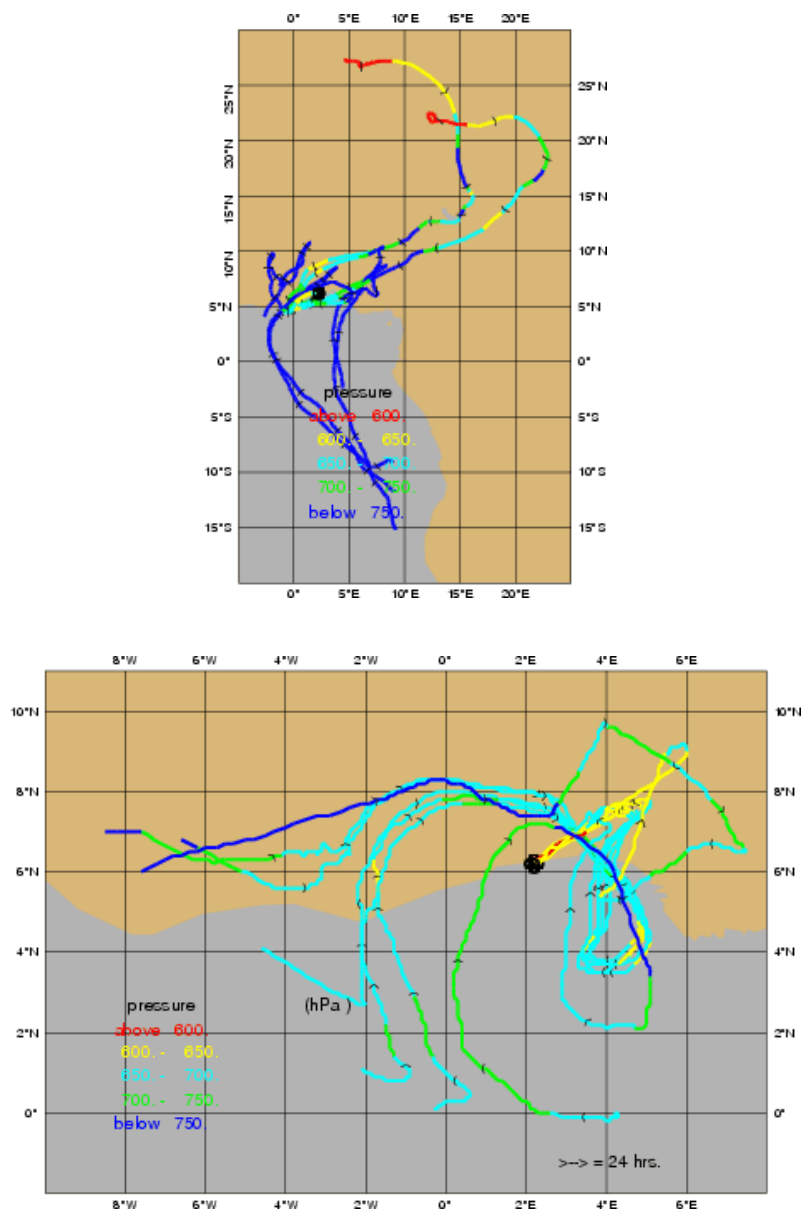

Fig. 14. Ten day back trajectories ending at the Cotonou launch site $\left(6.2^{\circ} \mathrm{N}, 2.2^{\circ} \mathrm{E}\right)$ on the 3 (top) and 14 August (bottom), 2006. The black arrows indicate one-day time intervals along the back trajectory. The pressure levels through which each trajectory travels are shown using the same colour key as Fig. 13.

Africa (Reeves et al., 2010), an event which is not captured well in the model (cf. the top panel of Fig. 4).

Figure 15 shows the corresponding 10-day back trajectories initiated on the 13 of August along the flight path of the BAe-146 aircraft at the 09:00 $\mathrm{h}$ and 10:00 h, respectively (cf. Fig. 11), where peaks in both $\mathrm{CO}$ and $\mathrm{O}_{3}$ occur. Again, it can be clearly seen that the air circles the region anti-cyclonically for a few days preceding the day on which the measurement was taken. Again, when considering the high $\mathrm{CO}$ concentrations observed in the MOPITT composite (Reeves et al., 2010), the yellow pressure contours show that the height at which the air-masses reside coincides with polluted air-masses a few days before the measurement. Similar back trajectory calculations performed by AndréasHernández et al. (2009) have shown that polluted air sampled by the German Falcon (D-20) possibly originate from the MT $(\sim 500 \mathrm{hPa})$ to the west over Cameroon, although 

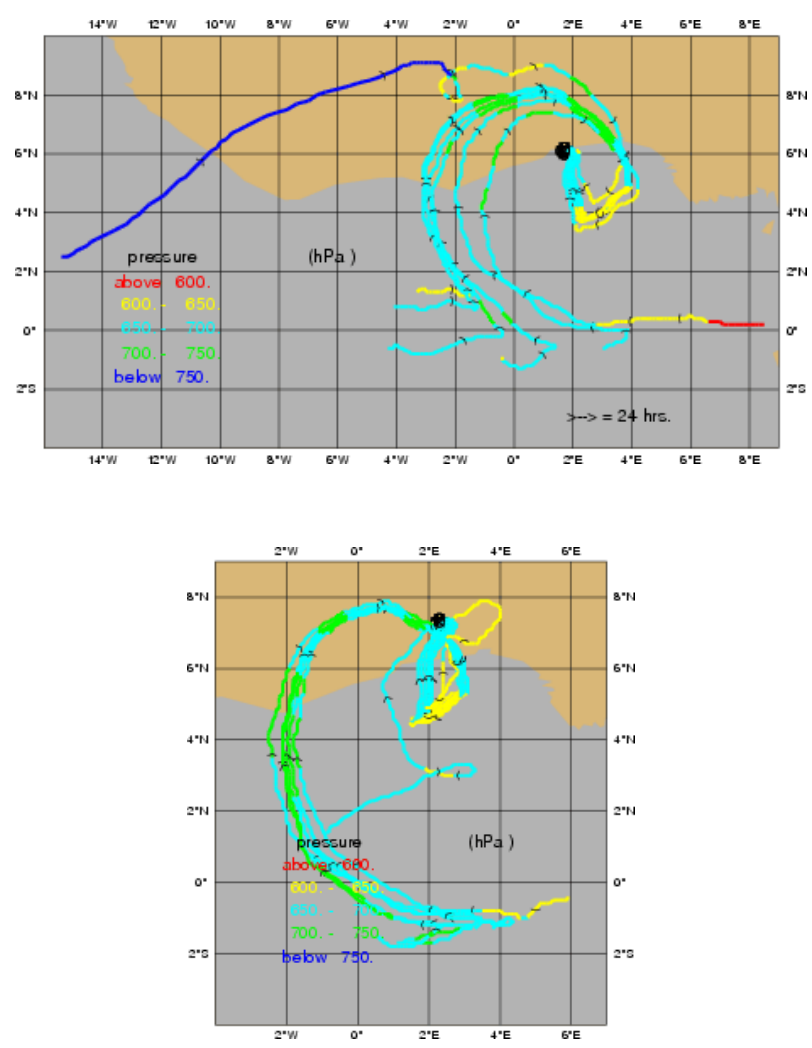

Fig. 15. Ten day back trajectories ending at the location of the BAe146 aircraft on 13 August at (top) 9 a.m. and (bottom) 10 am local time. The black arrows indicate one-day time intervals along the back trajectories. The numbers indicate the pressures at which the air starts and ends (in paranthesis). The colour coding also indicates pressure. The pressure levels through which each trajectory travels are shown using the same colour key as Fig. 13.

such trajectory calculations may have large uncertainity in the region (see below). Back trajectories performed for the flight shown in Fig. 12 (not shown) reveal that the air predominantly originates from the LT in North Africa, gradually rises as it travels south-west passing over the Sahel and Saharan regions resulting in $\mathrm{CO}$ and $\mathrm{O}_{3}$ mixing ratios which are more representative of the background. This air then mixes with that containing high $\mathrm{CO}$ signatures from $\mathrm{BB}$ in southern Africa explaining the high background CO in TM4_AMMA (cf. Fig. 10).

Finally, we also recalculated the trajectories shown in Figs. 13-15 using the meteorological dataset available for August 2006 which have assimilated the AMMA radio soundings (Agusti-Panareda et al., 2010). There is a strong impact of including the new measurements on the location of the AEJ-S in the ECMWF analysis. The trajectories presented here show that the inclusion of the additional measurements leads to significant differences in the origin of the trajectories. For brevity we do not show all the corresponding trajectories here but only those which exhibit the most interesting differences. Figure 16 shows the corresponding backward trajectories as those shown in the bottom panel of Fig. 14 (from Cotonou on the 14 August) and the top panel of Fig. 15 (from the BAe-146 flight path at 09:00 h on 13 August) using the updated meteorological fields. For the Cotonou sounding the origin of the air-mass is either directly from southern Africa or the LT of the Atlantic Ocean. For the BAe-146 flight, the air circulates in the same direction as that shown in the top panel of Fig. 13 and passes nearer Cameroon, which as region where BB occurs. Moreover, the forward trajectory calculations corresponding to Fig. 13 (not shown) indicate that a few more trajectories impinge on the coast (albeit in the LT) and more trajectories from Central Africa passing between $2^{\circ} \mathrm{S}-2^{\circ} \mathrm{N}$ around $500-600 \mathrm{hPa}$ as a result of a northward shift of the AEJ-S (Agusti-Panareda et al., 2010). This implies that the quality of the CTM simulations would improve if adopting the new meteorological dataset due to increases in $\mathrm{CO}$ and $\mathrm{O}_{3}$ transported in the AEJ$\mathrm{S}$, although the location of BB sources could still be inflentual.

\section{Further discussion}

The CTM simulations presented in this paper exemplify the difficulty that large scale 3D atmospheric models have in being able to capture both the horizontal and vertical distribution of $\mathrm{CO}$ and $\mathrm{O}_{3}$ as observed throughout the tropical troposphere around Africa. This behaviour has been seen across a range of different large scale CTMs (Williams et al., 2010). Such deficiencies are an integrated effect of inadequacies in model parameterizations e.g. convective transport, missing chemical processes e.g. aerosol formation and uncertainties associated with both the meteorological data fields used to drive the model and global inventories used to define the emission of chemical species from the surface due to various physical processes and anthropogenic activities. These factors subsequently place significant constraints on the degree of accuracy which can be achieved by any atmospheric model used for modeling tropical regions such as EA.

Bian et al. (2007) have examined the variability between different $\mathrm{BB}$ emission inventories for both northern and southern Africa and concluded that there are substantial differences in both the seasonality and the total emission flux for CO. For instance, in the GFEDv2 emission inventory BB emissions peak in August whereas other alternative inventories peak in September (Duncan et al., 2003; Arellano et al., 2004), where none of the emission inventories represent the burning season well. Moreover, Bian et al. (2007) state that the emissions estimates in the GFEDv2 inventory are too high when compared to MOPITT, although we did not find this when comparing to the vertical profiles measured by MOZAIC in Sect. 4. More recently, the new AMMABB inventory developed by Liousse et al. (2010) increases the emission of trace gases substantially in Africa 

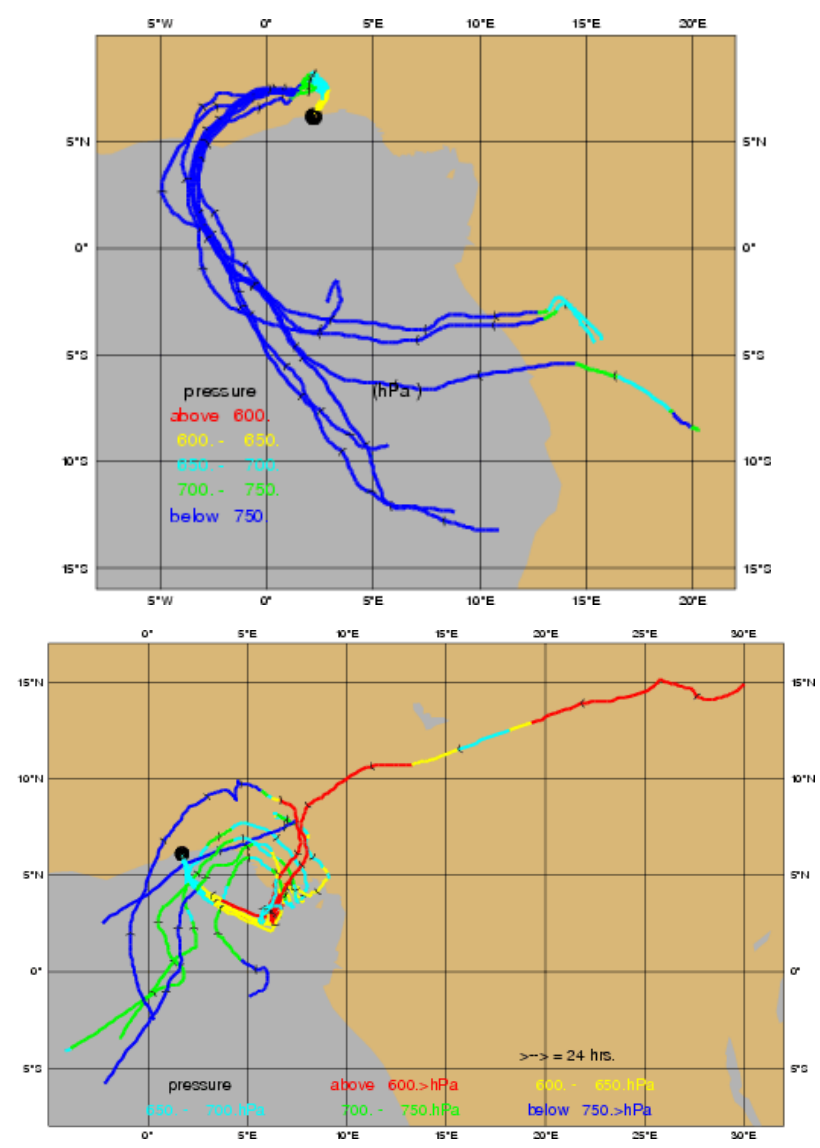

Fig. 16. Ten day back trajectories using the new ECMWF meteorological dataset which assimilates additional sounding information taken during AMMA (Agusti-Panareda et al., 2010). The trajectories shown are (top) for the Cotonou measurement site starting on the 14 August (corresponding with the bottom panel in Fig. 11) and (bottom) for the BAe-146 flight on the 13 August at 9 a.m. local time (corresponding with the top panel in Fig. 12). The pressure levels through which each trajectory travels are shown using the same colour key as Fig. 13.

when compared to GFEDv2 using a similar seasonality (Stroppiana et al., 2010). However, we have shown that increasing the emission flux of CO for JJA by $50 \%$ in the GFEDv2 8-day inventory only makes a marginal improvement for the burning region, whilst significantly overestimating the background concentrations as a result of transport towards Northern Africa. Differences will also exist in the temporal distribution of such inventories, where some quantification of the scale of these anomalies would be helpful for the global and regional modelling communities.

When comparing the large scale and seasonal variability in the meteorology which affects EA throughout the year (Grist and Nicholson, 2003) one major problem concerns capturing an accurate description of the dominant events due to inadequecies in the sampling frequency of meteorological parameters in the region. The various backward trajectory simu- lations discussed in Sect. 5 show that over a typical month the large scale circulation can change dramatically influencing transport both into and out of EA. Such under sampling introduces problems with respect to the description of transport in large scale atmospheric models which use these meteorological data fields to calculate the long range transport of pollutants between regions. The large temperature and moisture gradients in the lower troposphere are particularly important in determining the correct atmospheric dynamics in the Sahel region between $\sim 12-20^{\circ} \mathrm{N}$, which encompasses the Guinea region defined in this study. This could go some way towards explaining the too efficient transport of BB plumes from southern Africa over the region in which the AMMA aircraft campaign took place (cf. Fig. 10). Given that 2006 was a unique year, where many additional meteorological measurements were available as part of the dedicated AMMA measurement campaign, means that typically there remains a large degree of uncertainty associated with modeling the region during the WAM. Although the re-analysis of meteorological data is ongoing there is still a limit to which such datasets can be improved due to the existing sampling frequency of past measurements.

\section{Conclusions}

In this study we have investigated the influence that regional biomass burning emissions from southern and northern Africa have on the composition of the lower and middle troposphere over Equatorial Africa during the West African Monsoon in 2006. By performing a set of sensitivity studies we have shown that emissions from southern Africa between $0-40^{\circ} \mathrm{S}$ dominate tropospheric composition over Equatorial Atlantic for this season, and influence a large area in the Northern Hemisphere between $\sim 10-20^{\circ} \mathrm{N}$. When using the GFEDv2 monthly biomass burning emission inventory and 6-hourly ECMWF meteorological fields, the maximum concentrations of $\mathrm{CO}$ and $\mathrm{O}_{3}$ occur between $0-5^{\circ} \mathrm{S}$ during August, which is more southerly than the distribution observed in MOPITT satellite observations (Reeves et al., 2010). This finding agrees with that previously seen when adopting the alternative AMMABB emission inventory by Liousse et al. (2010) in a number of independent chemistry transport models (Williams et al., 2010). This is due to the African Easterly Jet - South being too far south as defined in the ECMWF meteorological analysis used to drive the model (Agusti-Panareda et al., 2010).

For tropospheric $\mathrm{CO}$, comparisons made against in-situ measurements taken from the MOZAIC programme reveal that TM4_AMMA generally underpredicts CO in the lower to middle troposphere near the source regions, indicating that the emission flux for $\mathrm{CO}$ is either too low in the GFEDv2 biomass burning inventory or the temporal distribution of burning events is not accurate. Comparisons made against a MOPITT composite for July and August (Reeves et al., 2010) 
show that the transport across the equator in the model is too weak over the gulf of Guinea between $0-5^{\circ} \mathrm{N}$, again partly due to the position of the African Easterly Jet - South. Directly above Equatorial Africa $\left(6-20^{\circ} \mathrm{N}\right)$ comparisons made against a composite of the measurements taken during the intensive AMMA aircraft campaign show that TM4_AMMA generally exhibits too high $\mathrm{CO}$ in the lower and middle troposphere as a result of the over efficient transport of biomass burning plumes from southern Africa $\left(0-40^{\circ} \mathrm{S}\right)$ into the region, where an anti-correlation is observed between the model and the measurements in the lower troposphere between $8-20^{\circ} \mathrm{N}$.

For tropospheric $\mathrm{O}_{3}$, comparisons made against ozonesonde measurements reveal that the vertical distribution is generally good near the source regions, whilst being too high (low) in the lower (middle) troposphere in Western Africa. Using a set of trajectory studies we show that the transport of biomass burning plumes from southern Africa influences the lower troposphere over the region rather than the middle troposphere, thus constraining the performance of the model.

By varying both the temporal resolution and injection heights at which biomass burning emissions are introduced into the model we have shown that increasing the temporal variability of the biomass burning emissions has a larger effect near the biomass burning source regions, where a degradation occurs in the model in the lower troposphere below $750 \mathrm{hPa}$. Altering the temporal resolution also has a larger effect than altering the effective injection height on the simulated variability in both $\mathrm{CO}$ and $\mathrm{O}_{3}$ in the outflow regions to the west of Africa over the Gulf of Guinea. This agrees with the findings of Chen et al. (2009) for northern boreal fire regions. Above Equatorial Africa, away from the source regions, the improvements introduced by both modifications are marginal for this season.

Analysing the origin of air for a number of "extreme" events where very high $\mathrm{O}_{3}$ concentrations were observed using 10-day backward trajectories we have shown that using the ECMWF meteorological analysis the air typically circles over the Gulf of Guinea mixing with air influenced by biomass burning plumes. Using a special meterological reanalysis assimilating additional radiosonde measurements taken during AMMA we show that the transport in the region is poorly constrained due to the complex meteorology which occurs during the West African Monsoon. Thus, the use of trajectory analysis around Equatorial Africa for determining whether an air parcel originates from a region exhibiting biomass burning should be treated with caution without a corresponding chemical signature such as acetonitrile.

Acknowledgements. The authors acknowledge the EU integrated project AMMA (African Monsoon Multidisciplinary Analysis, contract 004089-2) for the support network and funding. Based on a French initiative, AMMA was built by an international scientific group and is currently funded by a large number of agencies, especially from France, the United Kingdom, the United States and
Africa. It has been the beneficiary of a major financial contribution from the European Community Sixth Framework Research Programme. Detailed information on scientific co-ordination and funding is available on the AMMA International Web site at www.amma-international.org. JEW also acknowledges the EU integrated project SCOUT-O3 (Stratospheric-Climate links with emphasis On the Upper Troposphere and lower stratosphere, contract 505390-GOCE-CT-2004) for partial funding of this work. We also achknowledge the strong support of the European Comission, Airbus, Lufthansa, Austrian Airlines and Air France, who carry the MOZAIC instrumentation free of charge and have performed maintenance sinde 1994. MOZAIC is currently funded by INSU-CNRS (France), Meteo-France and Forschungzentrum Julich, Germany. The MOZAIC data base is supported by ETHER (CNES and INSU-CNRS). Additionally we acknowledge the RETRO (EVK2-CT-2002-00170) EU project for providing the anthropogenic emission inventories used in this study. We thank P. Le Sager for helpful tips regarding IDL programming. Finally we thank the anonymous referees for their critical comments on the manuscript.

Edited by: P. Formenti

\section{References}

Agusti-Panareda, A., Beljaars, A., Cardinali, C., Genkova, I., and Thorncroft, C.: Impact of assimilating AMMA soundings on ECMWF analyses and forecasts, Weather Forcast., 25(4), 1142$1160,2010$.

Andreae, M. O. and Merlet, P.: Emission of trace gases and aerosols from biomass burning, Global Biogeochem. Cy., 15(4), 955-966, 2001.

Andrés-Hernández, M. D., Kartal, D., Reichert, L., Burrows, J. P., Meyer Arnek, J., Lichtenstern, M., Stock, P., and Schlager, H.: Peroxy radical observations over West Africa during AMMA 2006: photochemical activity in the outflow of convective systems, Atmos. Chem. Phys., 9, 3681-3695, doi:10.5194/acp-93681-2009, 2009.

Ancellet, G., Leclair de Bellevue, J., Mari, C., Nedelec, P., Kukui, A., Borbon, A., and Perros, P.: Effects of regional-scale and convective transports on tropospheric ozone chemistry revealed by aircraft observations during the wet season of the AMMA campaign, Atmos. Chem. Phys., 9, 383-411, doi:10.5194/acp-9-3832009, 2009.

Arellano Jr., A. F., Kasibhatla, P. S., Giglio, L., van der Werf, G. R., and Randerson, J. T.: Top-down estimates of global CO sources using MOPITT measurements, Geophys. Res. Lett., 31, L01104, doi:10.1029/2003GL018609, 2004.

Barret, B., Ricaud, P., Mari, C., Attié, J.-L., Bousserez, N., Josse, B., Le Flochmoën, E., Livesey, N. J., Massart, S., Peuch, V.H., Piacentini, A., Sauvage, B., Thouret, V., and Cammas, J.P.: Transport pathways of $\mathrm{CO}$ in the African upper troposphere during the monsoon season: a study based upon the assimilation of spaceborne observations, Atmos. Chem. Phys., 8, 3231-3246, doi:10.5194/acp-8-3231-2008, 2008.

Bian, H., Chen, M., Kawa, R., Duncan, B., Arellano, A., and Kasibhatla, K.: Sensitivity of global CO simulations to uncertainties in biomass burning sources, J. Geophys. Res., 112, D23308, doi:10.1029/2007JD008376, 2007. 
Boersma, K. F., Jacob, D. J., Eskes, H. J., Pinder, R. W., Wang, J., and van der A, R. J., Intercomparison of SCIAMACHY and OMI tropospheric $\mathrm{NO}_{2}$ columns: Observing the diurnal evolution of chemistry and emissions from space, J. Geophys. Res., 113, D16S26, doi:10.1029/2007JD008816, 2008.

Chen, Y., Li, Q., Randerson, J. T., Lyons, E. A., Kahn, R. A., Nelson, D. L., and Diner, D. J.: The sensitivity of CO and aerosol transport to the temporal and vertical distribution of North American boreal fire emissions, Atmos. Chem. Phys., 9, 6559-6580, doi:10.5194/acp-9-6559-2009, 2009.

Colarco, P. R., Schoberl, M. R., Dodderidge, B. G., Marufu, L. T., Torres, O., and Welton, E. J.: Transport of smoke from Canadian forest fires to the surface near Washington, D. C.: Injection height, entrainment, and optical properties, J. Geophys. Res., 109, D06203, doi:10.1029/2003JD004248, 2004.

Crutzen, P. J. and Andreae, M. O.: Biomass burning in the tropics: Impact on atmospheric chemistry and biogeochemical cycles, Science, 250, 1669-1678, 1990.

de Laat, A. T. J., Gloudemans, A. M. S., Schrijver, H., van den Broek, M. M. P., Meirink, J. F., Aben, I., and Krol, M.: Quantitative analysis of SCIAMACHY carbon monoxide total column measurements, Geophys. Res. Lett., 33, L07807, doi:10.1029/2005GL025530, 2006.

de Laat, A. T. J., van der A, R. J., and van Weele, M.: Evaluation of tropospheric ozone columns derived from assimilated GOME ozone profile observations, Atmos. Chem. Phys., 9, 8105-8120, doi:10.5194/acp-9-8105-2009, 2009.

Deshler, T., Mercer, J., Smit, H. G. J., et al.: Atmospheric comparison of electrochemical cell ozonesoundes from different manufacturers, and with different cathode solution strengths: The Balloon Experiment on Standards for Ozone sondes, J. Geophys. Res., 113, D04307, doi:10.1029/2007JD008975, 2008.

Duncan, B. N., Martin, R. V., Staudt, A. C., Yevich, R., and Logan, J. A.: Interannual and seasonal variability of biomass burning emissions constrained by satellite observations, J. Geophys. Res., 108, D24100, doi:10.1029/2002JD002378, 2003.

Edwards, D. P., Emmons, L. K., Gille, J. C., Chu, A., Attie, J.-L., Giglio, L., Wood, S. W., Haywood, J., Deeter, M. N., Massie, S. T., Ziskin, D. C., and Drummond, J. R.: Satellite-observed pollution from Southern Hemisphere biomass burning, J. Geophys. Res., 111, D14312, doi:10.1029/2005JD006655, 2006.

Flanningan, M. D., Krawchuk, M. A., de Groot, W. J., Wotton, B. M., and Gowman, L. M.: Implications of changing climate for global wildland fire, Int. J. Wild. Fire, 18(5), 483-507, doi:10.1071/WF08187, 2009.

$\mathrm{Fu}, \mathrm{Q} .:$ An accurate parameterization of the solar radiative properties of cirrus clouds for climate models, J. Climate, 9, 20582082, 1996.

Giglio, L.: Characterization of tropical diurnal fire cycle using VIRS and MODIS observations, Remote Sens. Environ., 108, 407-421, 2007.

Heymsfield, A. J. and McFarquhar, G. M.: High albedos of cirrus in the tropical pacific warm pool: Microphysical interpretations from CEPEX and from Kwajalein, Marshall Islands, J. Atmos. Sci., 53, 2424-2451, 1996.

Heymsfield, A. J.: Properties of Tropical and Midlatitude Ice Cloud Particle Ensembles. Part II: Applications for Mesoscale and Climate Models, J. Atmos. Sci., 60, 2592-2611, 2003.

Hobbs, P. V., Sinha, P., Yokelson, R. J., Christian, T. J., Blake, D. R.,
Gao, S., Kirchstetter, T. W., Novakov, T., and Pilewskie, P.: Evolution of gases and particles from a savanna fire in South Africa, J. Geophys. Res., 108(D13), 8485, doi:10.1029/2002JD002352, 2003.

Hoffmann, A. A., Parry, J. E., Cuambe, C., Kwesha, D., and Zhakata, W., Climate chnage and wildland fires in Mozambique, in: Tropical Fire Ecology: Climate change, Land Use and Ecosystem Dynamics, edited by: Cochrane, M., Springer Praxis, 227-260, 2009.

Houweling, S., Dentener, F. J., and Lelieveld, J.: The impact of nonmethane hydrocarbon compounds on tropospheric photochemistry, J. Geophys. Res., 103(D9), 10673-10696, 1998.

Huijnen, V., Williams, J., van Weele, M., van Noije, T., Krol, M., et al.: The global chemistry transport model TM5: description and evaluation of the tropospheric chemistry version 3.0, Geophys. Model. Dev., 3, 445-473, doi:10.5194/gmd-3-445-2010, 2010.

Ito, A. and Penner, J. E.: Estimates of $\mathrm{CO}$ emissions from open biomass burning in southern Africa for the year 2000, J. Geophys. Res., 110, D19306, doi:10.1029/2004JD005347, 2005.

Jacob, D. J.: Heterogeneous chemistry and tropospheric ozone, Atmos. Environ., 34, 2131-2159, 2000.

Jain, A. K.: Global estimation of CO emissions using three sets of satellite data for burned area, Atmos. Environ., 41, 6931-6940, 2007.

Janicot, S., Thorncroft, C. D., Ali, A., Asencio, N., Berry, G., Bock, O., Bourles, B., Caniaux, G., Chauvin, F., Deme, A., Kergoat, L., Lafore, J.-P., Lavaysse, C., Lebel, T., Marticorena, B., Mounier, F., Nedelec, P., Redelsperger, J.-L., Ravegnani, F., Reeves, C. E., Roca, R., de Rosnay, P., Schlager, H., Sultan, B., Tomasini, M., Ulanovsky, A., and ACMAD forecasters team: Large-scale overview of the summer monsoon over West Africa during the AMMA field experiment in 2006, Ann. Geophys., 26, 25692595, doi:10.5194/angeo-26-2569-2008, 2008.

Jost, C., Trentmann, J., Sprung, D., Andreae, M. O., McQuaid, J. B., and Barjat, H.: Trace gas chemistry in a young biomass burning plume over Namibia: Observations and model simulations, J. Geophys. Res., 108, 8482, doi:10.1029/2002JD002431, 2003.

Kahn, R. A., Li, W.-H., Moroney, C., Diner, D. J., Martonchik, J. V., and Fishbein, E.: Aerosol source plume physical characteristics from space-based multiangle imaging, J. Geophys. Res., 112, D11205, doi:10.1029/2006JD007647, 2007.

Kahn, R. A., Chen, Y., Nelson, D. L., Leung, F.-Y., Li, Q., Diner, D. J., and Logan, J. A.: Wildfire Smoke Injection Heights Two Perspectives from Space, Geophys. Res. Lett., 35, L04809, doi:10.1029/2007GL032165, 2008.

Kull, C. A. and Laris, P., Fire ecology and fire politics in Mali and Madagascar, in: Tropical Fire Ecology: Climate change, Land Use and Ecosystem Dynamics, edited by: Cochrane, M., Springer Praxis, 171-226, 2009.

Labonne, M., Breon F.-M., and Chevallier, F.: Injection height of biomass burning aerosols as seen from a spaceborne lidar, Geophys. Res. Lett., 34, L11806, doi:10.1029/2007GL029311, 2007.

Leung, F.-Y., T., Logan, J. A., Park, R., Hyer, E., Kasischke, E., Streets, D., and Yurganov, L.: Impact of enhanced biomass burning in the boreal forests in 1998 on tropospheric chemistry and the sensitivity of model results to the injection height of emissions, J. Geophys. Res., 112, D10313, doi:10.1029/2006JD008132, 2007.

Liousse, C., Guillaume, B., Grégoire, J. M., Mallet, M., Galy, C., 
Pont, V., Akpo, A., Bedou, M., Castéra, P., Dungall, L., Gardrat, E., Granier, C., Konaré, A., Malavelle, F., Mariscal, A., Mieville, A., Rosset, R., Serça, D., Solmon, F., Tummon, F., Assamoi, E., Yoboué, V., and Van Velthoven, P.: Updated African biomass burning emission inventories in the framework of the AMMAIDAF program, with an evaluation of combustion aerosols, Atmos. Chem. Phys., 10, 9631-9646, doi:10.5194/acp-10-96312010, 2010.

Mari, C. H., Cailley, G., Corre, L., Saunois, M., Attié, J. L., Thouret, V., and Stohl, A.: Tracing biomass burning plumes from the Southern Hemisphere during the AMMA 2006 wet season experiment, Atmos. Chem. Phys., 8, 3951-3961, doi:10.5194/acp-8-3951-2008, 2008.

Monks, P. S., Granier, C., Fuzzi, S., Stohl, A., et al.: Atmospheric composition change - global and regional air quality, Atmos. Environ., 43, 5268-5350, 2009.

Muhle, J., Brenninkmeijer, C. A. M., Rhee, T. S., Slemr, F., Oram, D. E., Penkett, S. A., and Zahn, A.: Biomass burning and fossil fuel signatures in the upper troposphere observed during a CARIBIC flight from Namibia to Germany, Geophys. Res. Lett., 29(9), 1910, doi:10.1029/2002GL015764, 2002.

Nedelec, P., Cammas, J.-P., Thouret, V., Athier, G., Cousin, J.-M., Legrand, C., Abonnel, C., Lecoeur, F., Cayez, G., and Marizy, C.: An improved infrared carbon monoxide analyser for routine measurements aboard commercial Airbus aircraft: technical validation and first scientific results of the MOZAIC III programme, Atmos. Chem. Phys., 3, 1551-1564, doi:10.5194/acp-3-15512003, 2003.

Nicholson, S. E. and Grist, J. P.: The Seasonal Evolution of the Atmospheric Circulation over West Africa and Equatorial Africa, J. Climate, 16, 1013-1030, 2003.

Petterssen, S.: Weather Analysis and Forecasting, McGraw-Hill, 221-223, 1940.

Real, E., Orlandi, E., Law, K. S., Fierli, F., Josset, D., Cairo, F., Schlager, H., Borrmann, S., Kunkel, D., Volk, C. M., McQuaid, J. B., Stewart, D. J., Lee, J., Lewis, A. C., Hopkins, J. R., Ravegnani, F., Ulanovski, A., and Liousse, C.: Cross-hemispheric transport of central African biomass burning pollutants: implications for downwind ozone production, Atmos. Chem. Phys., 10, 3027-3046, doi:10.5194/acp-10-3027-2010, 2010.

Redelspeger, J. L., Thorncroft, C. D., Diedhiou, A., Lebel, T., Parker, D. J., and Polcher, J.: African Monsoon Multidisiplinary Analysis - An international research project and field campaign, B. Am. Meteorol. Soc., 87, 1739-1746, 2006.

Reeves, C. E., Formenti, P., Afif, C., Ancellet, G., Attié, J.-L., Bechara, J., Borbon, A., Cairo, F., Coe, H., Crumeyrolle, S., Fierli, F., Flamant, C., Gomes, L., Hamburger, T., Jambert, C., Law, K. S., Mari, C., Jones, R. L., Matsuki, A., Mead, M. I., Methven, J., Mills, G. P., Minikin, A., Murphy, J. G., Nielsen, J. K., Oram, D. E., Parker, D. J., Richter, A., Schlager, H., Schwarzenboeck, A., and Thouret, V.: Chemical and aerosol characterisation of the troposphere over West Africa during the monsoon period as part of AMMA, Atmos. Chem. Phys., 10, 7575-7601, doi:10.5194/acp-10-7575-2010, 2010.

Roberts, G., Wooster, M. J., and Lagoudakis, E.: Annual and diurnal african biomass burning temporal dynamics, Biogeosciences, 6, 849-866, doi:10.5194/bg-6-849-2009, 2009.

Sauvage, B., Thouret, V., Cammas, J.-P., Gheusi, F., Athier, G., and Nédélec, P.: Tropospheric ozone over Equatorial Africa: regional aspects from the MOZAIC data, Atmos. Chem. Phys., 5, 311335, doi:10.5194/acp-5-311-2005, 2005.

Sauvage, B., Thouret, V., Thompson, A. M., Witte, J. C., Cammas, J.-P., Nédélec, P., and Athier, G.: Enhanced view of the "tropical Atlantic ozone paradox" and "zonal wave one" from the in situ MOZAIC and SHADOZ data, J. Geophys. Res., 111, D01301, doi:10.1029/2005JD006241, 2006.

Sauvage, B., Gheusi, F., Thouret, V., Cammas, J.-P., Duron, J., Escobar, J., Mari, C., Mascart, P., and Pont, V.: Medium-range midtropospheric transport of ozone and precursors over Africa: two numerical case studies in dry and wet seasons, Atmos. Chem. Phys., 7, 5357-5370, doi:10.5194/acp-7-5357-2007, 2007.

Scheele, M. P., Siegmund, P. C., and van Velthoven, P. F. J.: Sensitivity of trajectories to data resolution and its dependence on the starting point: in or outside a tropopause fold, Meteor.Appl., 3, 267-273, 1996.

Schmitt, C. G. and Heymsfield, A. J.: Total Surface Area Estimates for Individual Ice Particles and Particle Populations,J. Appl. Meteor., 44, 467-474, 2005.

Sinha, P., Jaeglé, L., Hobbs, P. V., and Liang, Q.: Transport and biomass burning emissions from southern Africa, J. Geophys. Res., 109, D20204, doi:10.1029/2004JD005044, 2004.

Staudt, A. C., Jacob, D. J., Logan, J. A., Bachiochi, D., Krishnamurti, T. N., and Poisson, N.: Global chemical model analysis of biomass burning and lightning influences over the South Pacific in austral spring, J. Geophys. Res., 107(D14), 4200, doi:10.1029/2000JD000296, 2002.

Stevenson, D. S., Dentener, F. J., Schultz, M. G., Ellington, K., et al.: Multi-model ensemble simulations of present-day and near-future tropospheric ozone, J. Geophys. Res., 111, D08301, doi:10.1029/2005JD006338, 2006.

Stohl, A., Haimberger, L., Scheele, M. P., and Wernli, H.: Am intercomparison of results from three trajectory models, Meteor. Appl., 8, 127-135, 2001.

Stroppiana, D., Brivio, P. A., Grégoire, J.-M., Liousse, C., Guillaume, B., Granier, C., Mieville, A., Chin, M., and Pétron, G.: Comparison of global inventories of monthly $\mathrm{CO}$ emissions derived from remotely sensed data, Atmos. Chem. Phys. Discuss., 10, 17657-17697, doi:10.5194/acpd-10-17657-2010, 2010.

Thompson, A., Witte, J. C., Oltmans, S. J., Schmidlin, F. J., Logan, J. A., Fuijwara, M., Kirchhoff, V. W. J. H., Posny, F., Coetzee, G. J. R., Hoegger, B., Kawakami, S., Ogawa, T., Fortuin, J. P. F., and Kelder, H. M.: Southern Hemisphere Additional Ozonesondes (SHADOZ) 1998-2000 tropical ozone climatology 2. Tropospheric variability and the zonal wave-one, J. Geophys. Res., 108, 8241, doi:10.1029/2002JD002241, 2003.

Thouret, V., Marenco, A., Logan, J. A., Nédélec, P., and Grouhel, C.: Comparisons of ozone measurements from the MOZAIC airborne program and the ozone sounding network at eight locations, J. Geophys. Res., 103(D19), 25695-25720, 1998.

Thouret, V., Saunois, M., Minga, A., Mariscal, A., Sauvage, B., Solete, A., Agbangla, D., Nédélec, P., Mari, C., Reeves, C. E., and Schlager, H.: An overview of two years of ozone radio soundings over Cotonou as part of AMMA, Atmos. Chem. Phys., 9, 6157-6174, doi:10.5194/acp-9-6157-2009, 2009.

Turquety, S., Logan, J. A., Jacob, D. J., Hudman, R. C., Leung, F-Y., Heald, C. L., Yantosca, M., Wu, S., Emmons, L. K., Edwards, D. P., and Sachse, G. W.: Inventory of boreal fire emissions for North America in 2004: Importance of peat burning 
and pyroconvective injection, J. Geophys. Res., 112, D12S03, doi:10.1029/2006JD007281, 2007.

Van der A, R. J., Eskes, H. J., Boersma, K. F., van Noije, T. P. C., van Roozendael, M., De Smedt, I., Peters, D. H. M. U., and Meijer, E. W.: Trends, seasonal variability and dominant NOx source derived from a ten year record of $\mathrm{NO} 2$ measured from space, J. Geophys. Res., 113, D04302, doi:10.1029/2007JD009021, 2008.

Val Martin, M., Logan, J. A., Kahn, R. A., Leung, F.-Y., Nelson, D. L., and Diner, D. J.: Smoke injection heights from fires in North America: analysis of 5 years of satellite observations, Atmos. Chem. Phys., 10, 1491-1510, doi:10.5194/acp-10-14912010, 2010.

van der Werf, G. R., Randerson, J. T., Giglio, L., Collatz, G. J., Kasibhatla, P. S., and Arellano Jr., A. F.: Interannual variability in global biomass burning emissions from 1997 to 2004, Atmos. Chem. Phys., 6, 3423-3441, doi:10.5194/acp-6-3423-2006, 2006.
Williams, J. E., Scheele, M. P., van Velthoven, P. F. J., Cammas, J.-P., Thouret, V., Galy-Lacaux, C., and Volz-Thomas, A.: The influence of biogenic emissions from Africa on tropical tropospheric ozone during 2006: a global modeling study, Atmos. Chem. Phys., 9, 5729-5749, doi:10.5194/acp-9-5729-2009, 2009a.

Williams, J. E., van Zadelhoff, G.-J., and Scheele, M. P.: The effect of updating scavenging and conversion rates on cloud droplets and ice particles in the TM global chemistry transport model, KNMI technical report TR-308, 1-45, 2009 b.

Williams, J. E., Scheele, M. P., van Velthoven, P. F. J., et al.: Global Chemistry simulations in the AMMA MultiModel Intercomparison project, B. Am. Meteorol. Soc., 91, 611-624, 2010.

Zachariasse, M., van Velthoven, P. F. J., Smit, H. G. J., Lelieveld, J., Mandal, T. K., and Kelder, H.: Influence of stratospheretroposphere exchange on tropospheric ozone over the tropical Indian Ocean during the winter monsoon, J. Geophys. Res. 105, 15403-15416, 2000. 